\title{
SEISMOGEOLOGICAL, SEISMOLOGICAL AND ENGINEERING SEISMOLOGICAL STUDIES OF THE LABORATORY OF ENGINEERING SEISMOLOGY AND SEISMOGEOLOGY OF IEC RAS
}

Citation: Dzhurik V.I. 2014. Seismogeological, seismological and engineering seismological studies of the Laboratory of Engineering Seismology and Seismogeology of IEC RAS. Geodynamics \& Tectonophysics 5 (1), 135157. doi:10.5800/GT-2014-5-1-0121.

\section{СЕЙСМОГЕОЛОГИЧЕСКИЕ, СЕЙСМОЛОГИЧЕСКИЕ И ИНЖЕНЕРНО- СЕЙСМОЛОГИЧЕСКИЕ ИССЛЕДОВАНИЯ ЛАБОРАТОРИИ ИНЖЕНЕРНОЙ СЕЙСМОЛОГИИ И СЕЙСМОГЕОЛОГИИ ИЗК СО РАН}

\section{В. И. Джурик}

Институт земной коры СО РАН, Иркутск, Россия

Аннотация: Представляются в обобщенном виде результаты исследований, полученные за последние годы сотрудниками лаборатории по вопросам сейсмологии, сейсмогеологии и инженерной сейсмологии. Рассмотрены особенности проявления сейсмичности в различных регионах России, проведен анализ пространственно-временной и энергетической структуры сейсмичности и напряженно-деформированного состояния литосферы. Дается прогноз сейсмических воздействий сильных землетрясений на основания сооружений в различных районах БРЗ.

Ключевые слова: сейсмология, сейсмогеология, сейсмическое районирование, Байкальская рифтовая зона, прогноз сейсмических воздействий, сейсмогеодинамика, сейсмотектоника, структуры-аттракторы, рифтогенез, добротность. 


\section{1. ВВЕДЕНИЕ}

Исследования лаборатории инженерной сейсмологии и сейсмогеологии направлены на решение фундаментальной проблемы общей тектоники, геодинамики и сейсмической опасности - выявление закономерностей процессов сейсмотектонической деструкции земной коры и динамики сейсмогенерирующих структур зон коллизионного взаимодействия литосферных плит.

Для создания региональных сейсмогеодинамических моделей в лаборатории применяются новые геоинформационные системы управления базой данных сейсмотектонических параметров. Региональные модели будут использованы при уточнении исходного сейсмического балла существующих нормативных карт общего и детального сейсмического районирования.

Не менее важной задачей является определение основных закономерностей пространственно-энергетиче- ской структуры и эволюции напряженно-деформированного состояния литосферы и сейсмичности под воздействием процессов самоорганизации Байкальской рифтовой системы (БРС) с целью разработки научных основ прогноза сильных землетрясений и параметров их воздействий. Исследование активной нелинейной геофизической среды проводится впервые в мировой практике с целью развития и уточнения геодинамической модели неоднородного и неустойчивого напряженно-деформированного состояния литосферы, адекватно описывающей региональную, локальную и группирующуюся сейсмичность в условиях самоорганизации БРС.

Поставленные задачи решаются в процессе изучения исходной информации, накопленной за последние годы в Байкало-Монгольском регионе с использованием данных анализа сейсмотектонических особенностей территории и имеющихся сведений по слабым и силь-

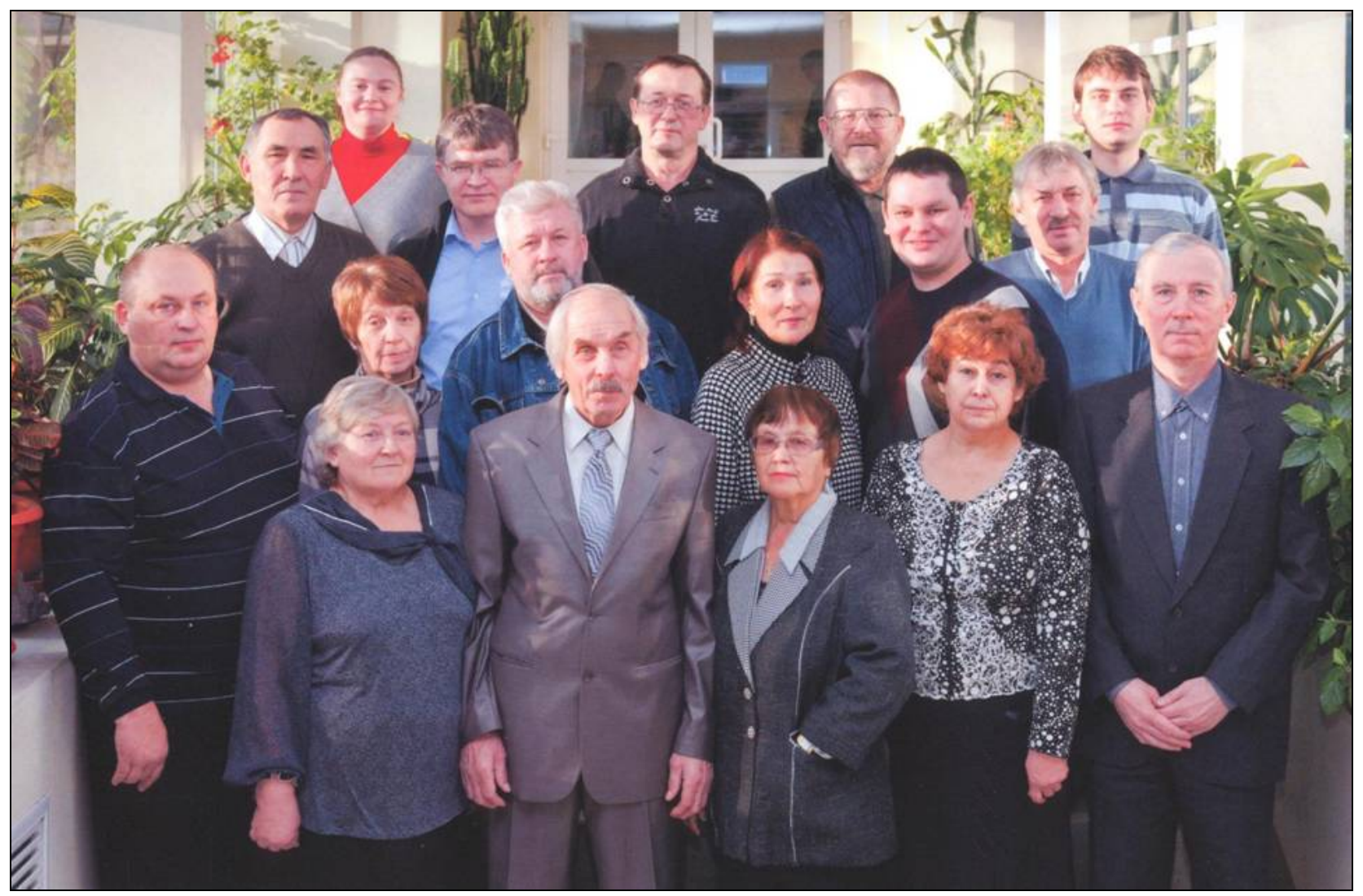

Рис. 1. Лаборатория инженерной сейсмологии и сейсмогеологии.

Слева на право: 1-й ряд - В.Е. Максименко, д.г.-м.н. В.И Джурик - заведующий лабораторией, Л.Г. Соснина, Г.Н. Масленникова, д.г.-м.н А.В. Ключевский; 2-й ряд - к.г.-м.н. А.Ю. Ескин, Н.Н. Дреннова, В.С. Баскаков, к.г.-м.н. Л.П. Имаева, А.Н. Шагун, к.г.-м.н. С.П. Серебренников; 3-й ряд - д.г.-м.н. А.В. Чипизубов, к.ф.-м.н. А.А. Добрынина, к.г.-м.н. О.П. Смекалин, В.М. Демьянович, д.г.-м.н В.С. Имаев, Е.В. Брыжак

Fig. 1. The Laboratory staff.

$1^{\text {st }}$ row - V.E. Maximenko, V.I. Dzurik (Head of the Laboratory), L.G. Sosnina, G.N. Maslennikova, A.V. Klyuchevsky; $2^{\text {nd }}$ row - A.Yu. Eskin, N.N. Drennova, V.S. Baskakov, L.P. Imaeva, A.N. Shagoon, S.P. Serebrennikov; $3^{\text {rd }}$ row - A.V. Chipizubov, A.A. Dobrynina, O.P. Smekalin, V.M. Dem’yanovich, V.S. Imaev, E.V. Bryzhak 
ным землетрясениям, получения в натурных условиях новых данных по комплексу методов геологии и геофизики.

Исследования проводятся в рамках общей тематики проекта НИР «Сейсмотектонические процессы и прогноз сейсмических воздействий сильных землетрясений Байкало-Монгольского региона». В общероссийском плане они отвечают приоритетному направлению развития фундаментальной науки в РФ № VIII.78 «Катастрофические эндогенные и экзогенные процессы, включая экстремальные изменения космической погоды: проблема прогноза и снижения уровня негативных последствий».

Основная цель проводимых исследований - использование полученных данных при планировании строительства в сейсмоактивных районах БРЗ, что будет способствовать снижению риска последствий от сейсмических катастроф. В статье будут изложены некоторые полученные результаты исследований по отмеченным и другим вопросам, а также перспективы развития лаборатории.

\section{2. ИСТОРИЧЕСКАЯ СПРАВКА}

История лаборатории начинается в 1963 г., когда профессором д.ф.-м.н. А.А. Тресковым, главой сибирской сейсмологической школы, была организована служба инструментальных сейсмических наблюдений в Байкальской сейсмической зоне и создана лаборатория сейсмологии. После исследований профессором В.П. Солоненко и его группой Гоби-Алтайского землетрясения (1957 г.) было создано сейсмогеологическое подразделение, которое вскоре оформилось в лабораторию инженерной сейсмогеологии. В 1970 году к.г.-м.н. О.В. Павловым, координатором комплексных геолого-геофизических исследований сейсмической опасности трассы БАМ и других промышленных объектов Восточной Сибири и Монголии, была создана лаборатория инженерной сейсмологии. До слияния лабораторий заведующими были к.г.-М.н. В.М. Кочетков (лаборатория сейсмологии), к.ф.-м.н. А.В. Солоненко (лаборатория физики землетрясений), д.г.-м.н. В.А. Потапов (лаборатория общей и инженерной сейсмологии), В.И. Джурик (кабинет сейсмокриолитозоны) и д.г.-м.н. В.С. Имаев (лаборатория сейсмогеологии).

В настоящее время лаборатория инженерной сейсмологии и сейсмогеологии, созданная в 2011 г., насчитывает 23 сотрудника, включая 5 докторов и 8 кандидатов наук. Заведующий лабораторией д.г.-м.н В.И. Джурик (рис. 1).

\section{3. ОСНОВНЫЕ НАУЧНЫЕ НАПРАВЛЕНИЯ}

Лаборатория проводит исследования по фундаментальным и прикладным разделам сейсмологии, сейс- могеологии и инженерной сейсмологии. Они включают:

- проблемы очаговой сейсмологии, сейсмического режима, напряженно-деформированного состояния литосферы, количественной оценки сейсмичности, сейсмического районирования разной степени детальности, изучение динамики сейсмических волн в структурно-неоднородных средах и прогноз сейсмических воздействий на грунты и сооружения;

- разработку и совершенствование методов количественной оценки сейсмической опасности, совершенствование и дальнейшую разработку методов палеосейсмогеологического анализа, развитие методов долго- и среднесрочного прогноза сильных землетрясений для Прибайкалья и смежных территорий, напряженнодеформированного состояния геологической среды в зонах активных разломов, а также подготовку пакета новых карт потенциальных очагов землетрясений Восточной Сибири.

\section{4. АППАРАТУРНО-ПРИБОРНАЯ БАЗА ЛАБОРАТОРИИ}

Аппаратура, используемая в экспедициях, включает в себя: GPS-приемники, материалы лазерного сканирования, лазерные дальномеры и уровнемеры; среднеи малоглубинная геофизическая аппаратура: сейсморазведочная инженерная станция «Лакколит 24-М», низкочастотная электроразведочная аппаратура Электротест-С, электроразведочная аппаратура ЕРА-MАХ (измерения ВЭЗ, ВП и ЕП); сейсмостанции для регистрации землетрясений, взрывов, вибраций, микросейсм: «Байкал-6», «Байкал-7HR», «Байкал-8»; сейсмодатчики (CK-1П, CM-3КВ, ОСП 2M) и другие вспомогательные приборы и оборудование.

\section{5. НАУЧНЫЕ ДОСТИЖЕНИЯ ПРОШЛОГО}

Из научных достижений прошлого можно отметить следующие:

- карта сейсмического районирования СССР (масштаб 1:5000000), М.: Наука,1984;

- из 8-томника «Геология и сейсмичность территории БАМ», Новосибирск: Наука, 1985, три тома («Сейсмичность», «Инженерная геология и инженерная сейсмология», «Сейсмогеология и сейсмическое районирование») являются результатом работ в основном сотрудников предшествующих и настоящей лаборатории;

- официально изданные карты общего сейсмического районирования Российской Федерации ОСР-97 (соавторы В.С. Имаев, Л.П. Имаева, В.С. Хромовских);

- карта общего сейсмического районирования Российской Федерации ОСР-2012 (соавторы В.С. Имаев, Л.П. Имаева, О.П. Смекалин, А.В. Чипизубов, Р.М. Семенов); 


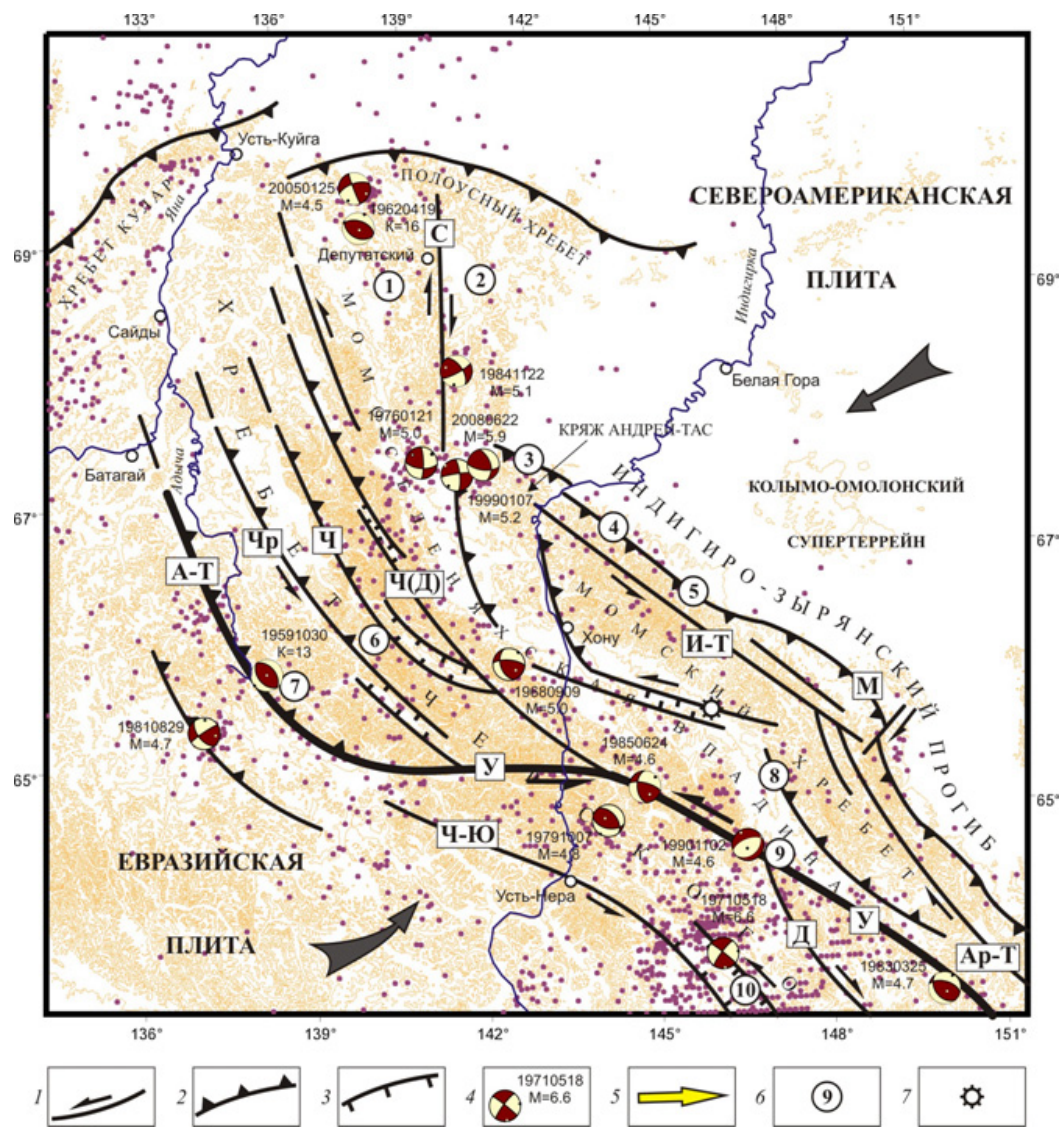

Рис. 2. Схема сейсмотектоники Яно-Индигирского сегмента сейсмотектонической зоны Черского.

1-3 - разломы: 1 - сдвиги, 2 - надвиги, 3 - сбросы; 4 - механизм очагов сильных землетрясений с указанием их даты и магнитуды, белым цветом обозначены области сжатия; 5 - направление относительного движения плит; 6 - места позднекайнозойских взбросо-сдвиговых деформаций (1 - Верхнеселенняхская, 2 - Инач, 3 - Сисиктех, Никондя, 4 - Кыллах, 5 - Мятись, Элгандя, 6 - Чаркынская, 7 Ченкеленьинская, 8 - Нижнемомская, 9 - Улахан, 10 - Верхненерская); 7 - местоположение вулкана Балаган-Тас. Буквами обозначены названия главных разломов: А-Т - Адыча-Тарынский, Чр - Чаркынский, Ч - Чемалгинский, Ч(Д) - Чибагалахский (Догдинский), С - Селенняхский; У - Улахан, Д - Дарпир, Ч-Ю - Чай-Юреинский, М - Мятисский, И-Т - Илин-Тасский, Ар-Т - Арга-Тасский. Крапом нанесены эпицентры инструментально зарегистрированных землетрясений.

Fig. 2. The scheme of seismotectonics of the Yano-Indigirka segment of the Chersky seismotectonic zone.

1-3 - faults: 1 - strike-slip, 2 - thrust, 3 - normal; 4 - strong earthquake focal mechanism, dates and magnitudes (compression areas are shown in white); 5 - relative plate movement directions; 6 - sites of the Late Cenozoic overthrust-shear deformation (1 - Verkhnaselennyakhskaya, 2 - Inach, 3 - Sisiktekh, Nikondya, 4 - Kyllakh, 5 - Myatus, Elgandya, 6 - Charkynskaya, 7 - Chenkelen'inskaya, 8 - Nizhnemomskaya, 9 - Ulakhan, 10 - Verkhnenerskaya); 7 - location of Balagan-Tas volcano. Main fault names: A-T - Adycha-Tarynsky, Чp - Charkynsky, Ч - Chemalginsky, Ч(Д) - Chibagalakhsky (Dogdinsky), C - Selennyakhsky; У - Ulakhan, Д - Darpir, Ч-Ю - Chai-Yureinsky, M - Myatissky, И-Т - Ilin-Tassky, Ap-T - Arga-Tassky. Speckles show epicentres of instrumentally recorded earthquakes.

- патент на изобретение «Способ краткосрочного прогноза землетрясения»; авторы: Р.М. Семенов, В.С. Имаев, А.Р. Семенов, А.И. Оргильянов, О.П. Смекалин, Н.П. Широкобокова; патентообладатель: государственное образовательное учреждение высшего профессионального образования Иркутский государственный университет путей сообщения.

\section{6. ОСНОВНЫЕ НАУЧНЫЕ ДОСТИЖЕНИЯ}

Основные научные достижения представляются кратко за время существования новой лаборатории по отмеченным выше основным направлениям и согласно планам НИР.

\section{1. СЕЙСМОГЕОДИНАМИКА ГОРНО-СКЛАДЧАТОГО ОБРАМЛЕНИЯ СИБИРСКОЙ ПЛАТФОРМЫ: СЕЙСМИЧЕСКИЙ ПРОЦЕСС, СЕЙСМОТЕКТОНИКА И СЕЙСМОБЕЗОПАСНОСТЬ}

В рамках работы лаборатории группой сейсмогеологии решены задачи, которые сгруппированы в несколько отдельных направлений, связанных с особенностями установления сейсмогеодинамической обстановки отдельных районов горно-складчатого обрамления Сибирского кратона. 
Проанализированы кинематические типы сейсмогенерирующих структур, а также морфотектонические особенности современного рельефа и соответствующие им поля тектонических напряжений Яно-Индигирского сегмента сейсмотектонической зоны Черского с целью создания модели современной геодинамики территории [Имаева, Имаев и др., 2011]. Установлено, что здесь в условиях транспрессии (сжатия со сдвигом) имеет место определенная кинематическая обстановка, обусловленная взаимодействием сопряженных разнонаправленных сдвигов. Подобные условия возможно смоделировать, если представить, что при сближении Северо-Американской и Евразийской литосферных плит роль активного индентора выполняет Колымо-Омолонский блок (супертеррейн), находящийся во фронтальной части Северо-Американской плиты. Установленный кинематический план системы активных разломов подтверждает унаследованность позднекайнозойских деформаций от мезозойской структуры и свидетельствует о том, что сейсмогенерирующие структуры развиваются в кинематической ситуации, определяемой взаимодействием фронтальных зон Евразийской и Северо-Американской литосферных плит, движущихся с разными скоростями [Имаева u дp., 2012]. Полученные результаты детальных сейсмотектонических исследований могут являться основой анализа геодинамических режимов, а также сейсмогеодинамических построений для отдельных сегментов сейсмических поясов северо-востока Азии. Выполненная работа знаменует важный теоретический этап в процессе познания природы сейсмотектонической деструкции земной коры, что позволяет провести определение степени сейсмической опасности территорий на новом качественном уровне (рис. 2).

Структурная организация сейсмогенерирующих зон отдельных сегментов сейсмотектонической зоны Черского свидетельствует о режиме транспрессии (сжатия со сдвигом), обусловленной взаимодействием сближающихся с разными скоростями Евразийской и Северо-Американской литосферных плит (рис. 2).

Таким образом, анализ особенностей сейсмотектонического режима, выявление типов сочленений плит и блоков, а также системы активных разрывных структур Индигиро-Колымского сегмента и проявлений сейсмичности на их границах позволяет прогнозировать характер сейсмотектонических процессов, а также их возможное развитие в пространстве [Имаева, Козьмин и др., 2012].

На основе комплекса геолого-структурных, сейсмологических и сейсмотектонических исследований, проведенных в зоне взаимодействия северо-восточного фланга Байкальской рифтовой зоны и Олекмо-Становой сейсмической зоны, выявлена общая геодинамическая позиция и определены закономерности формирования активных разломов области перехода рифтовых структур растяжения к структурам сжатия (рис. 3). Установлено, что закономерности в проявлении сейс- мичности, характере полей тектонических напряжений и развитии определенных парагенезисов разломов, возникших в переходной зоне, определяют мозаику развивающихся разломно-блоковых структур (РБС), которые образовались при взаимодействии (транспрессии - сжатии со скольжением) Байкало-Витимского (Забайкальского) и Западно-Станового блоков морфоструктурных элементов современного рельефа и в ориентации нодальных плоскостей фокальных механизмов землетрясений [Имаева, Мельникова и др., 2012].

На основе новых обобщенных геолого-структурных, сейсмологических, сейсмотектонических, наземных геодезических и GPS-данных изучены общая геодинамическая позиция Алдано-Станового блока, его современный структурно-тектонический план и закономерности структурообразования активных разломов в разнородном поле тектонических напряжений, обусловленных взаимодействием Евроазиатской и Амурской литосферных плит на юге Восточной Сибири (Забайкалье), в Южной Якутии и Приамурье [Смекалин и др., 2010; Имаева, Имаев и др., 2012].

За время выполнения работ были проведены сейсмотектонические исследования по установлению закономерностей в эволюции сейсмического процесса и развитии системы активных разломов в пределах Монголо-Азиатского орогенного пояса. В настоящее время территория характеризуется высокой тектонической активностью. Большинство сейсмоактивных зон в прошлом веке были отмечены землетрясениями с M>7.0. Однако остаются еще и такие, сейсмичность которых за период инструментальных наблюдений не превышала фоновых значений, а сейсмический потенциал определяется наличием палеосейсмогенных дислокаций. Одна из таких зон установлена в окрестностях г. Улан-Батора и прослеживается в северо-восточном простирании через Керуленскую впадину в направлении Забайкалья, в район Урулюнгуйской впадины [Имаев, Смекалин и др., 2012].

Впервые выраженные в рельефе предположительно активные разломы на территории Южного Забайкалья и Северной Монголии были установлены в конце 50-х годов прошлого века после катастрофического ГобиАлтайского землетрясения. Однако многие из выделенных тогда линеаментов до недавнего времени не были обследованы сейсмогеологическим методом. Возможно, это связано с тем, что ядро этого мегасвода располагается с восточной стороны от условной меридиональной $\left(103^{\circ}\right.$ в.д.) границы, делящей территорию Монголии на западную, высокосейсмичную, и восточную, практически асейсмичную, части.

Сотрудниками сейсмогеологического отряда ИЗК СО РАН совместно с геофизиками Северо-Восточного федерального университета, в сотрудничестве с монгольскими и западноевропейскими коллегами были детально изучены и откартированы сейсмогенерирующие Хустайский, Эмелтский, Гунжинский и Верх- 


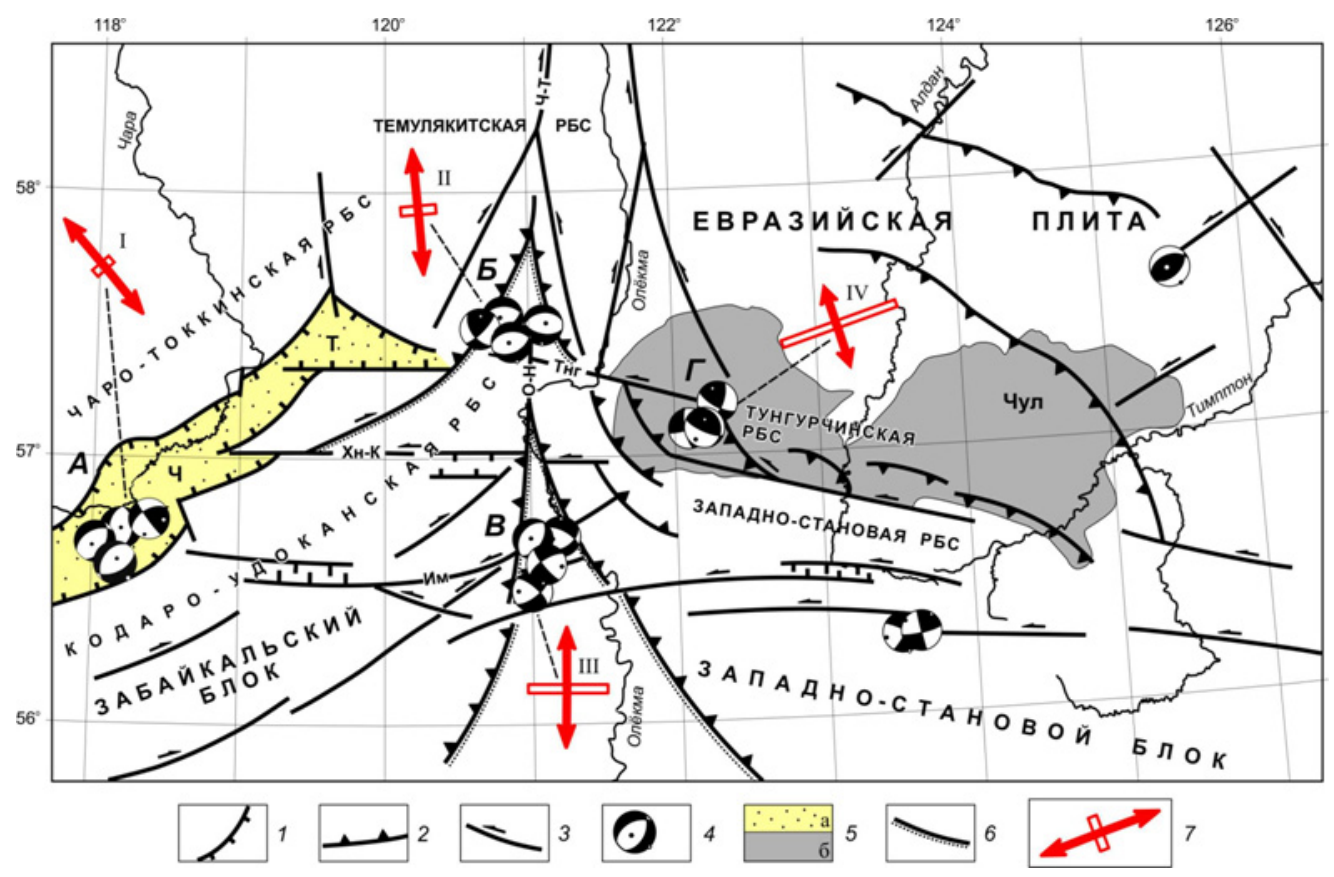

Рис. 3. Сейсмотектоническая схема северо-восточного фланга БРЗ и сопряженной системы сейсмогенерирующих структур Западно-Станового блока.

Крупные глубинные региональные разломы, активизированные в кайнозое: 1 - сбросы; 2 - взбросы, надвиги, 3 - сдвиги (Хн-К - ХаниКудулинский, Тнг - Тунгурчинский, Ч-Т - Чаро-Темулякитский, О-Н - Олёкмо-Нюкженский, Им - Имангрский); 4 - диаграммы фокальных механизмов землетрясений с $M=4.7-7.0$ в проекции нижней полусферы (темными и светлыми точками обозначены выходы осей сжатия и растяжения); 5 - впадины: а - кайнозойские: Ч - Чарская, Т - Токкинская; б - мезозойская: Чул - Чульманская; 6 - границы зон взаимодействия структур; 7 - горизонтальная проекция главных осей сейсмотектонических деформаций (красные расходящиеся стрелки - удлинение, светлые - укорочения): I - режим растяжения, II, III - переход от сдвига к растяжению; IV - переход от сдвига к сжатию. Эпицентральные поля: А - Чарское, Б - Олдонгсинское (Чаруодинское), В - Олекминское, Г - Южно-Якутское.

Fig. 3. The seismotectonic scheme of the north-eastern flank of the Baikal rift zone and the conjugated system of structures in the West Stanovoy block, which generate seismicity.

Large deep regional faults reactivated in the Cenozoic: 1 - normal; 2 - overthrust, thrust; 3 - strike-slip (Xн-K - Khani-Kudulinsky, THг - Tungurchinsky, Ч-Т - Charo-Temulyakitsky, O-H - Olyokmo-Nukzhensky, Им - Imangrsky); 4 - diagram of earthquake focal mechanisms, $M=4.7-$ 7.0 in the lower hemisphere projection (dark and light dots show solutions of compression and extension axes); 5 - basins: a - Cenozoic: Ч Chara, T - Tokka; 6 - Mesozoic: Чул - Chul'man; 6 - boundaries of interaction zones between structures; 7 - horizontal projection of major axes of seismotectonic deformation (red divergent arrows show elongation; light arrows show shortening): I - extension regime, II, III - transition from shear to extension, IV - transition from shear to compression. Epicentral fields: A - Charskoe, Б - Oldongsinskoe (Charuodinskoe), B - Olyokminskoe, $\Gamma$ - Yuzhno-Yakutskoe.

некеруленский разломы, представляющие реальную угрозу для столицы Монголии и аймачного центра г. Баганнур [Дэмбэрэл и др., 2010].

Комплексный анализ материалов дистанционных методов (космических снимков, объемных моделей рельефа поверхности), сейсмогеологические исследования (геоморфологические наблюдения, тренчинг, геофизические малоглубинные исследования) позволили получить информацию о характере строения этих сейсмогенных разломов, фиксируемых деформациях в разрезах толщ вблизи выхода плоскости смещения на поверхность, определить генетический тип и кинематику самих разломов.

В результате проведенных работ впервые палеосейсмическими исследованиями подтвержден высокий сейсмический потенциал сейсмогенерирующих разломов монгольской части Хэнтэй-Даурского мегасвода, расположенных в непосредственной близости от столицы Монголии. Нами установлен сам факт наличия эпицентральных зон палеоземлетрясений и определены их качественные и количественные характеристики (кинематика, амплитуда смещения, абсолютный возраст). На новом фактическом материале оценено значение $\mathrm{M}_{\max }=7.0-7.4$ для Хустайского и Гунжинского сейсмогенерирующих разломов (Тольская зона ВОЗ). При этом мы считаем обоснованной оценку возможной интенсивности сотрясений 8.0-8.5 балла по шкале MSK-64 для города Улан-Батора, обозначенную ранее на Карте сейсмического районирования Восточной Сибири и Монголии (карта сейсмического районирования Монголии).

В рамках актуализации действующей нормативной карты общего сейсмического районирования ОСР-97 и создания новой сейсмотектонической основы карты 


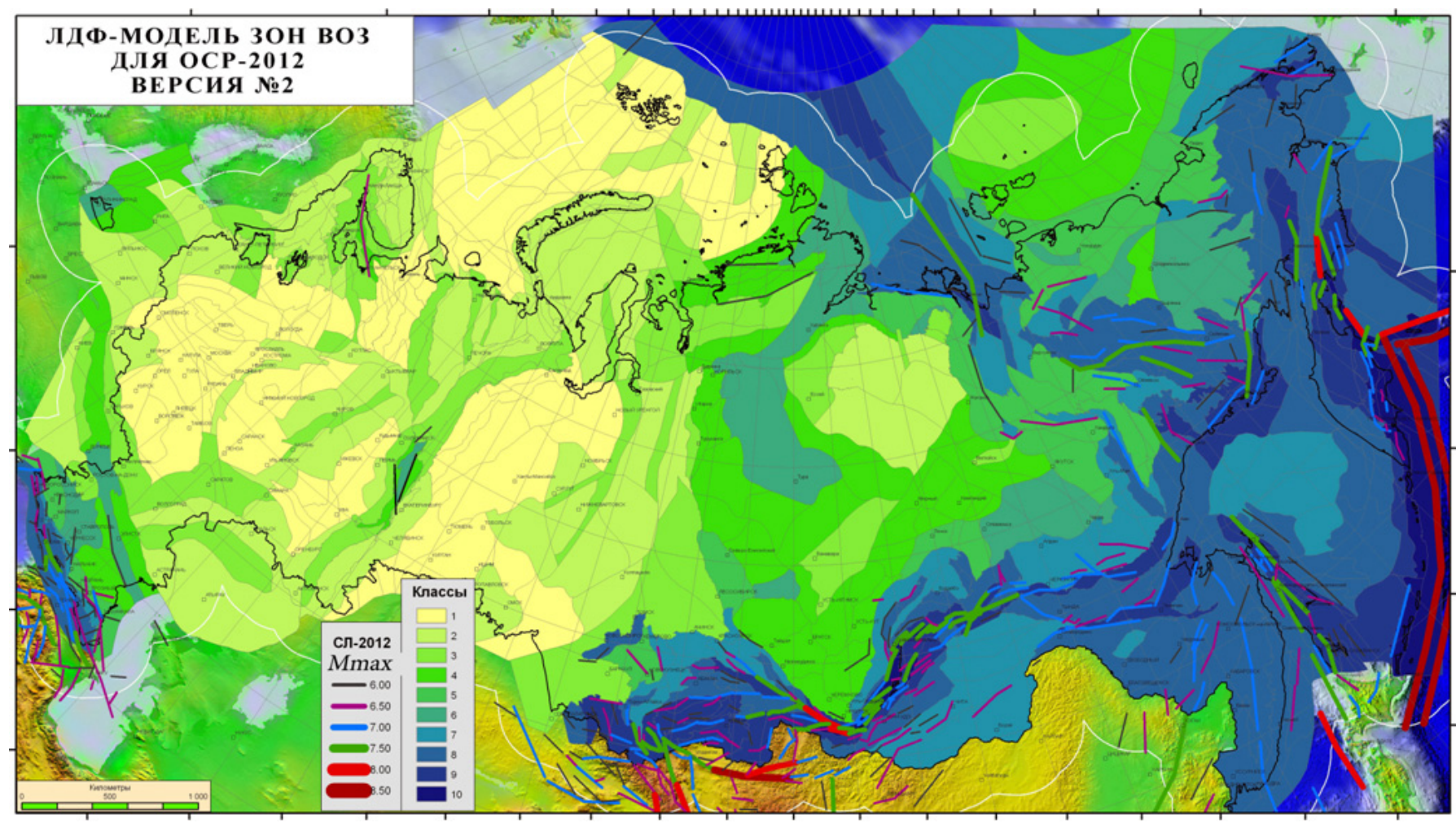

Рис. 4. Карта сейсмотектоники или ЛДФ-модель для карты ОСР-2012.

Fig. 4. The map of seismotectonics or LDF-model for OSR 2012 Map.

сейсмического районирования следующего поколения - ОСР-2012 - нами пересмотрены полученные ранее сейсмотектонические данные на территорию всей Восточной Сибири (Алтай-Саяно-Байкальский, Верхоянский и Приамуро-Приморский сейсморегионы). В основу сейсмотектонических исследований положена концепция о структурно-динамическом единстве геофизической среды и закономерно развивающихся в ней сейсмогеодинамических процессах, методические основы которой разработаны в Институте физики Земли РАН, а в дальнейшем дополнены и регионально адаптированы сотрудниками лаборатории сейсмогеологии ИЗК СО РАН [Mackey и дp., 2010; Fujita и дp., 2009]

В основу актуализации карт ОСР-97 и создания их усовершенствованной версии ОСР-97* положена методология вероятностного анализа сейсмической опасности (ВАСО), использованная и при создании комплекта карт ОСР в 1991-1997 гг. Существенным прогрессом за прошедшее с тех пор время явилось широкое привлечение компьютерного моделирования, геологических информационных систем (ГИС), формирование электронных баз данных и совершенствование программно-математического обеспечения для выполнения всех необходимых расчетов и построений. Сохранились принципы линеаментно-доменно-фокальной модели (ЛДФ-модель) зон возникновения очагов землетрясений (зоны ВОЗ).

В связи с тем, что к задачам сейсмотектонических и сейсмогеодинамических исследований относятся выявление и сейсмологическая параметризация сейсмогенерирующих структур (СГС) для создания корректных моделей зон ВОЗ на территории России и в сопредельных регионах, их первоначальное выделение и параметризация происходят путем комплексного анализа и выделения геодинамически активных неотектонических зон (ГАНЗ), которые могут генерировать сильные землетрясения. ГАНЗ, с позиции системного анализа, рассматривается как пространственно локализованный целостный объект с многофакторным взаимодействием его основных компонентов в разрезе земной коры и верхней мантии (литосфере) - коровомантийный вариант, в разрезе литосферы и нижней мантии - суперглобальный вариант.

Составлены схемы сейсмотектоники или линеаментно-доменно-фокальной модели территории Российской Федерации (электронная база данных в формате ArcView GIS) для актуализации действующей нормативной карты общего сейсмического районирования ОСР-97 и построения новой карты общего сейсмического районирования ОСР-2012, на которую в качестве нового элемента сейсмогенерирующих структур (доменов) вынесены отдельные классы ГАНЗ (рис. 4). 


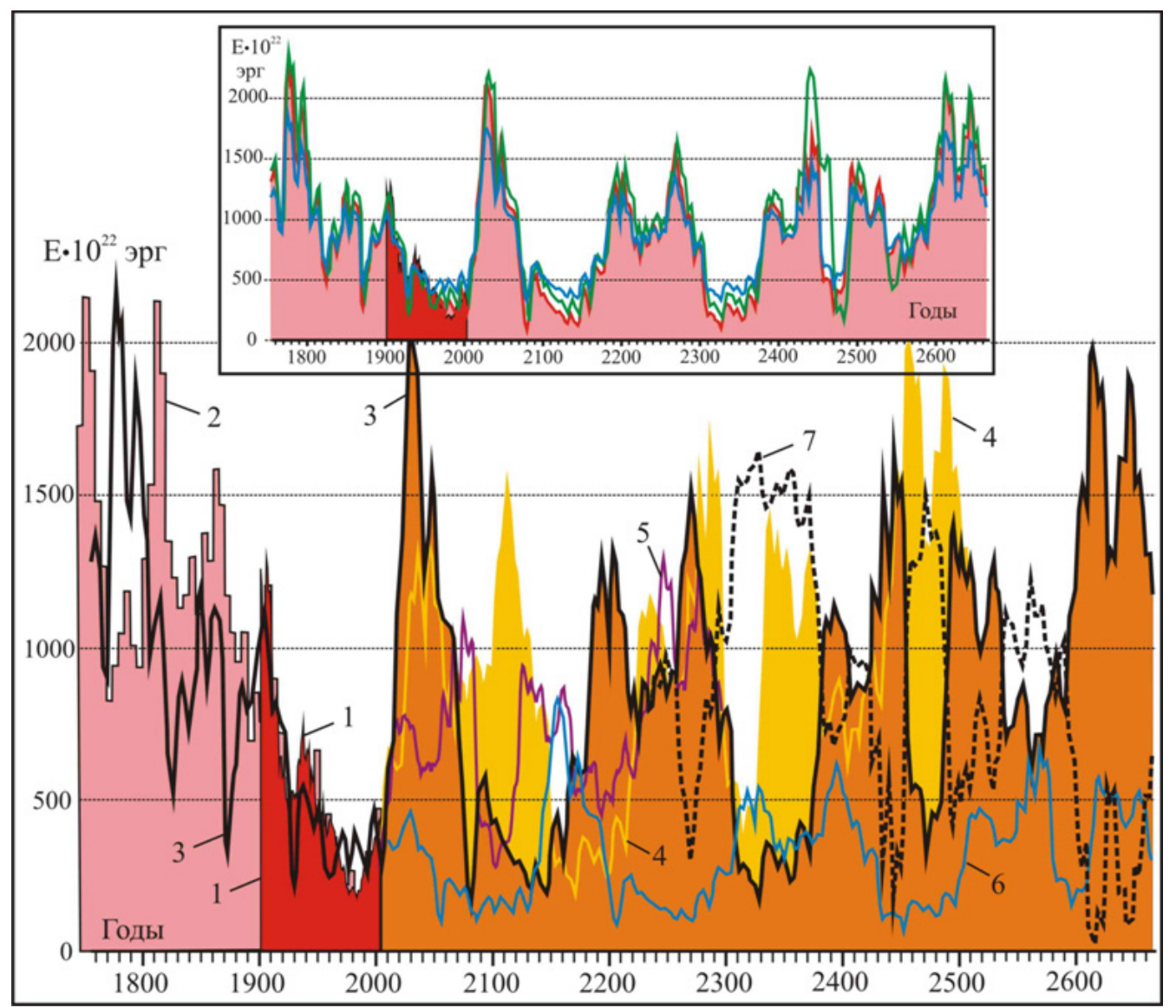

Рис. 5. Прогноз изменений сейсмичности по изменению различных процессов.

1 - ход сейсмичности по инструментальным данным; 2 - реконструированный ход сейсмичности; 3-6 - прогноз изменений сейсмичности по солнечной деятельности с различной инерционностью при условии сопоставимости наблюденных и реконструированных $\mathrm{W}: 3$ ход сейсмичности и его прогнозная часть (коричневая заливка) при наиболее реальной инерционности 662 г., 4 - инерционность 506 лет, 5 - инерционность 298 лет, 6 - инерционность 787 лет; 7 - прогноз при условии противофазного хода наблюденных и реконструированных W. На врезке линиями различного цвета отражен прогноз изменений сейсмичности $\left(\mathrm{E}_{5}\right)$ по изменению различных процессов: красный - по $\mathrm{W}_{11}$; синий - по $t_{5}$; зеленый - по $v_{5}$.

Fig. 5. Forecasting of changes in seismicity from changes of various processes.

1 - seismicity according to instrumental data; 2 - reconstructed seismicity; 3-6 - changes in seismicity as forecasted from data on solar activity with variable inertia on the condition of comparability of the observed and reconstructed W: 3 - seismicity and its forecasted part (brown) at the most realistic inertia of 662 years, 4 - inertia of 506 years, 5 - inertia of 298 years, 6 - inertia of 787 years; 7 - forecast on the condition of antiphase observed and reconstructed W. In the inserts, lines of different colours show forecasted changes in seismicity $\left(E_{5}\right)$ from changes of various processes: red - according to $\mathrm{W}_{11}$; blue - according to $t_{5}$; green - according to $v_{5}$.

На рис. 4 приведены границы сейсмогеодинамических регионов территории РФ, полученные на основе регионализации объектов с выделением ГАНЗ.

Подготовка и реализация очагов землетрясений оказывают влияние на изменение химического и газового состава подземных вод [Семенов, Имаев и др., 2010]. При этом их предсейсмические вариации часто являются предвестниками времени возникновения землетрясений. Так, в Южном Прибайкалье на основании изучения вариаций концентраций растворенного гелия в глубинной воде Байкала были выявлены краткосрочные предвестники сильного Култукского землетрясений 2008 г. [Семенов, Смекалин, 2011]. Возникновение этих вариаций, на наш взгляд, объясняется моделью подготовки и реализацией очага землетрясения. Из многих существующих в настоящее время моделей для Южного Прибайкалья, характеризующегося развитием рифтогенного процесса, наиболее подходящей является дилатантно-диффузная (ДД) модель.

27 августа 2008 г. в 10 час. 35 мин. местного времени (в 01 час. 35 мин. по Гринвичу) на юге Байкала произошло сильное землетрясение. Магнитуда землетрясения составляла $6.2(\mathrm{~K}=15.2)$, глубина очага 16 км, интенсивность сейсмических сотрясений в эпицентре достигала 8 баллов.

Нами с целью возможного выявления краткосрочных предвестников землетрясений проводится мониторинг содержания гелия в глубинной воде оз. Байкал 
в связи с изменением сейсмического режима. Работ подобного плана в открытых глубоководных водоемах, расположенных в сейсмически активных районах, таких как Байкал, пока не проводилось.

Перед Култукским землетрясением 27.08.2008 г. в содержаниях гелия отмечалось следующее. Сначала его количество увеличилось до $6.8310^{-5}$ мл/л, затем уменьшилось до 5.61, далее снова возросло до 6.02, а с 20.08 до 24.08 оставалось в пределах фона. Но ни разу содержание гелия не опускалось ниже фоновых значений. За два дня до землетрясения (25.08.2008 г.) содержание гелия уменьшилось ниже фона до 4.79, что соответствовало среднеквадратичному отклонению величины $2 \sigma$, и оставалось на этом уровне в течение 26.08.2008 г., а утром 27.08.2008 г. за два часа до землетрясения повысилось до 5.61. Сразу же после основного толчка и спустя час после землетрясения - повысилось до $6.02 \cdot 10^{-5}$ мл/л. После этого начался его спад, и 28.08.2008 г. содержания гелия снова установились на уровне фоновых значений [Семенов и др., 2010].

Подобные вариации концентраций гелия отмечались и перед некоторыми другими землетрясениями меньшего энергетического класса.

\section{2. ПЕРСПЕКТИВЫ ПРОГНОЗА ИЗМЕНЕНИЙ СЕЙСМИЧНОСТИ}

Сейсмичность - один из наиболее опасных природных процессов - является следствием тектонических движений, активность которых характеризуется значительными разнопорядковыми квазипериодическими изменениями. Это указывает на важность и необходимость исследований, направленных на прогноз изменений сейсмичности, что необходимо для оптимальной оценки сейсмической опасности [Чипизубов, 2008].

В целях надежного прогноза изменений сейсмичности Земли рассматривалась связь между развитием таких параметров геономических процессов, как скорость вращения Земли (отклонения $v$ за 1800-2000 гг., сейсмичность (энергия Е) землетрясений за 1896-2010 гг.) и изменчивость климата (отклонения глобальной температуры $(t)$ за последние 160 лет), и солнечной деятельностью (W) за 1090-2009 гг.

Взаимокорреляционный анализ сглаженных (11летние скользящие средние) временных рядов показал, что очень тесная связь наблюдается при запаздывании: $v$ на 367 лет $(\mathrm{R}=-0.89, \mathrm{n}=141) ; E$ на $298(\mathrm{R}=0.86$, $\mathrm{n}=104), 506$ лет $(\mathrm{R}=0.94, \mathrm{n}=104)$ и 662 года $(\mathrm{R}=0.86$, $\mathrm{n}=104) ; \boldsymbol{t}$ на 212 лет $(\mathrm{R}=0.91, \mathrm{n}=151)$ относительно солнечной деятельности. На основе полученных регрессионных соотношений предлагаются варианты прогноза изменений сейсмичности по динамике других процессов. На рис. 5 приведены эти варианты прогноза изменений сейсмичности Земли.

Проведенный анализ временных рядов рассматриваемых процессов позволяет сделать ряд выводов.
1. Ярко проявляющаяся 11-летняя цикличность в активности Солнца не находит адекватного отражения ни в одном из других рассматриваемых процессов, тогда как более продолжительные квазициклические гармоники проявляются во всех земных процессах.

2. Наиболее тесная $(\mathrm{R} \geq 0.86)$ связь геономических явлений с солнечной деятельностью наблюдается со значительной (сотни лет) инерционностью из-за различной скорости их протекания. Если в газообразной или даже, возможно, плазменной среде звездного объекта это практически мгновение, то в жидкой, пластичной и твердой среде сфер планеты процессы будут происходить с прогрессирующим замедлением.

3. Из предыдущих выводов следует, что солнечную деятельность можно рассматривать только в качестве индикатора изменчивости земных процессов, а не их источника.

4. Общая причина изменчивости процессов на Солнце, кроме собственной 11-летней цикличности, и на Земле связана с изменчивостью какого-то физического поля Вселенной.

5. Разновременность проявления изменчивости различных процессов будет основополагающим фактором при прогнозе изменений сейсмичности и других процессов. При этом величина запаздывания изменчивости одного явления по сравнению с другим напрямую связана с заблаговременностью прогноза.

6. Через 20-30 лет приемлемый прогноз изменений сейсмичности на сотни-тысячу лет по деятельности Солнца - «путеводной звезды» - будет реальностью.

\section{3. СТРУКТУРЫ-АТТРАКТОРЫ РИФТОГЕНЕЗА В ЛИТОСФЕРЕ БАЙКАЛЬСКОЙ РИФТОВОЙ СИСТЕМЫ И ИХ РОЛЬ В ФОРМИРОВАНИИ СОВРЕМЕННОЙ ГЕОДИНАМИКИ МОНГОЛО-БАЙКАЛЬСКОГО РЕГИОНА}

Установлено, что временные аттракторы напряжений в литосфере БРС соответствуют структуре «сборки» в рамках сценария эволюции с бифуркацией трехкратного равновесия [Klyuchevskii, 2010]. Эта бифуркация состоит в слиянии трех состояний равновесия: узлов $Q_{1}, Q_{2}$ и седла $Q_{0}$ между ними и образовании устойчивого узла в точке $Q_{0}$. Модельной системой для данной бифуркации служит уравнение изменений напряжений $S$ в виде:

$$
\frac{d}{d t} S=\alpha_{1}+\alpha_{2} S+S^{3}
$$

Анализ состояний равновесия (аттракторов) показывает, что при $\alpha_{2}>0$ и любом $\alpha_{1}$ система имеет единственное асимптотически устойчивое состояние равновесия $Q_{0}$. При $\alpha_{2}<0$ существует область значений $\alpha_{1}$, где система имеет три состояния равновесия. В фазопараметрическом пространстве системы фор- 
мируется структура, называемая сборкой. На основании этих соотношений предполагается, что коэффициенты в уравнении (1) имеют вид:

$$
\alpha_{1}=\frac{S_{h}-S_{V}}{S_{\max }}, \alpha_{2}=\frac{S_{H}-S_{V}}{S_{\max }},
$$

где $S_{\max }$ - максимальная из трех компонент напряжений. Тогда при $\alpha_{2}>0$ и любом $\alpha_{1}$ система имеет единственное асимптотически устойчивое состояние равновесия, характеризующее режим тектоники литосферных плит. При $\alpha_{2}<0$ существует область значений $\alpha_{1}$, в которой система может иметь три неустойчивых состояния равновесия, характеризующие современный режим рифтинга в БРС с неоднородным и нестационарным распределением напряжений.

Методы теории катастроф использованы для интерпретации топологии процесса разрушения горных пород при землетрясении. Поскольку многообразие катастрофы омбилики соответствует дискриминантному конусу, формируемому первыми вступлениями продольных $P$-волн при разрушении горных пород при землетрясении, высказана гипотеза, что очаг землетрясения отражает свойства универсальной катастрофы омбилики [Klyuchevskii, 2010]. В рамках этой гипотезы находит логическое объяснение катастрофический характер землетрясений, знакопеременность импульсов на сейсмограммах и самоподобие амплитудных спектров землетрясений.

Оценки и сопоставление энергии сейсмотектонических деформаций литосферы Байкальской рифтовой системы, определенной по данным о сильных землетрясениях с магнитудой $M \geq 6.0$ за период инструментальных наблюдений (1950-2002 гг.), исторический период продолжительностью 210 лет (1740-1949 гг.) и по палеосейсмогеологическим материалам за последние две тысячи лет, указывают на адекватность гипотезы стационарного сейсмического процесса [Ключевский, Демьянович, 2009; Ключевский и др., 2013]. Оценена мощность сейсмотектонических процессов, отражающих сброс эндогенной энергии посредством землетрясений. Полученные результаты характеризуют энергию и мощность сейсмотектонических деформаций литосферы БРЗ в абсолютных единицах, что удобно для проектирования и строительства. Выделение участков дефицита энергии сейсмотектонических деформаций литосферы («сейсмических брешей») является важным практическим результатом работы в рамках решения проблем обеспечения сейсмической безопасности в Байкальском регионе (рис. 6).

Исследование и обобщение данных параметров сейсмических источников позволили выделить в литосфере Байкальского региона три пространственные структуры-аттракторы рифтогенеза в районе ЮжноБайкальской, Хубсугульской и Муйской впадин [Клю- чевский, Демьянович, Джурик, 2009; Ключевский, 2011]. По данным о радиусах дислокаций здесь установлены области максимальной деформационно-прочностной анизотропии среды [Ключевский, 2009], а анализ сейсмических моментов землетрясений показал, что в этих областях литосферы происходят преимущественно толчки-сбросы разных энергетических классов [Ключевский, Демьянович и др., 2009; Ключевский, 2010], т.е. доминируют процессы рифтогенеза. В рамках теории нелинейных диссипативных динамических систем эти области классифицируются как пространственные структуры-аттракторы рифтогенеза (САР). САР расположены в центральной части и на флангах БРС (рис. 7): они формируют нелинейность и неустойчивость современных геодинамических и тектонофизических процессов в литосфере, которые проявляются в сейсмичности.

В соответствии с принципом актуализма полученные результаты исследования САР применены для развития и расширения представлений о кайнозойском этапе эволюции литосферы региона [Ключевский, 2011]. Выделение трех САР позволяет развить теорию современной геодинамики и тектонофизики БРС, включить в нее региональные энергетические источники геодинамических и сейсмических преобразований и описать в первом приближении их природу и эффекты. В рамках теории самоорганизации диссипативных динамических систем и нелинейных сред САР рассмотрены как атрибут кайнозойской геодинамики литосферы БРС: они формировали нелинейность и неустойчивость геодинамических и тектонофизических процессов в этот период времени. Три этапа вулканической активизации литосферы БРС объясняются последовательным зарождением и развитием трех САР: сначала в Южно-Байкальской впадине (поздний мел палеоцен), затем в Хубсугульской впадине (эоценолигоцен) и, наконец, в Муйской впадине (послеолигоцен). Начало кайнозойского рифтового этапа Байкальской впадины около 70 млн л. назад объясняется возникновением САР в Южно-Байкальской впадине. Две стадии «рифтинга», нарастание скорости рифтовых процессов в БРС и распространение рифтогенеза на юго-запад и северо-восток от Южно-Байкальской впадины, связываются с возникновением и последовательным двухсторонним развитием САР в Хубсугульской (юго-западный фланг) и Муйской (северо-восточный фланг) впадинах.

Разработаны тектонофизические основы генерации сильных землетрясений Байкальского региона. Показано, что механизм генерации сильных землетрясений Байкальского региона может быть связан с бифуркациями при гистерезисе нелинейного резонанса системы из трех осцилляторов - структур-аттракторов рифтогенеза в литосфере Байкальской рифтовой системы [Klyuchevskii, Khlebopros, 2013]. Данное исследование внутриконтинентальной рифтовой системы в рамках модели нелинейного осциллятора с диссипацией 


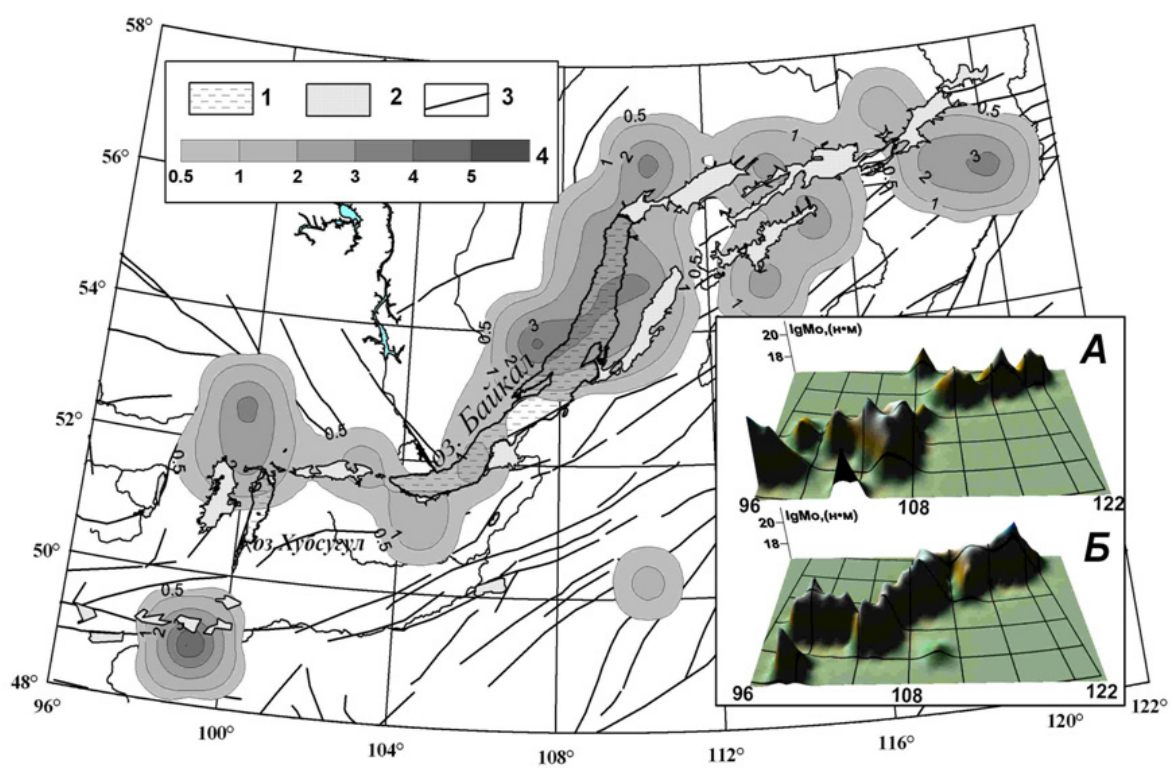

Рис. 6. Карта изолиний логарифма плотности мощности сейсмотектонических процессов со сбросом эндогенной энергии посредством землетрясений. На вставке дано 3D-представление поверхности логарифма плотности мощности сейсмотектонических процессов в инструментально-исторический $(A)$ и инструментальный (Б) периоды.

1 - озера; 2 - впадины; 3 - разломы; 4 - шкала изолинии логарифма плотности мощности.

Fig. 6. The map showing isolines of the logarithm of the density of magnitudes of seismotectonic processes associated with release of endogenous energy by earthquakes. The insert shows 3D surface of the logarithm of the density of magnitudes of seismotectonic processes in periods of historical instrumental $(A)$ and instrumental $(Б)$ measurements.

1 - lakes; 2 - basins; 3 - faults; 4 - scale of the intensity density logarithm isoline.

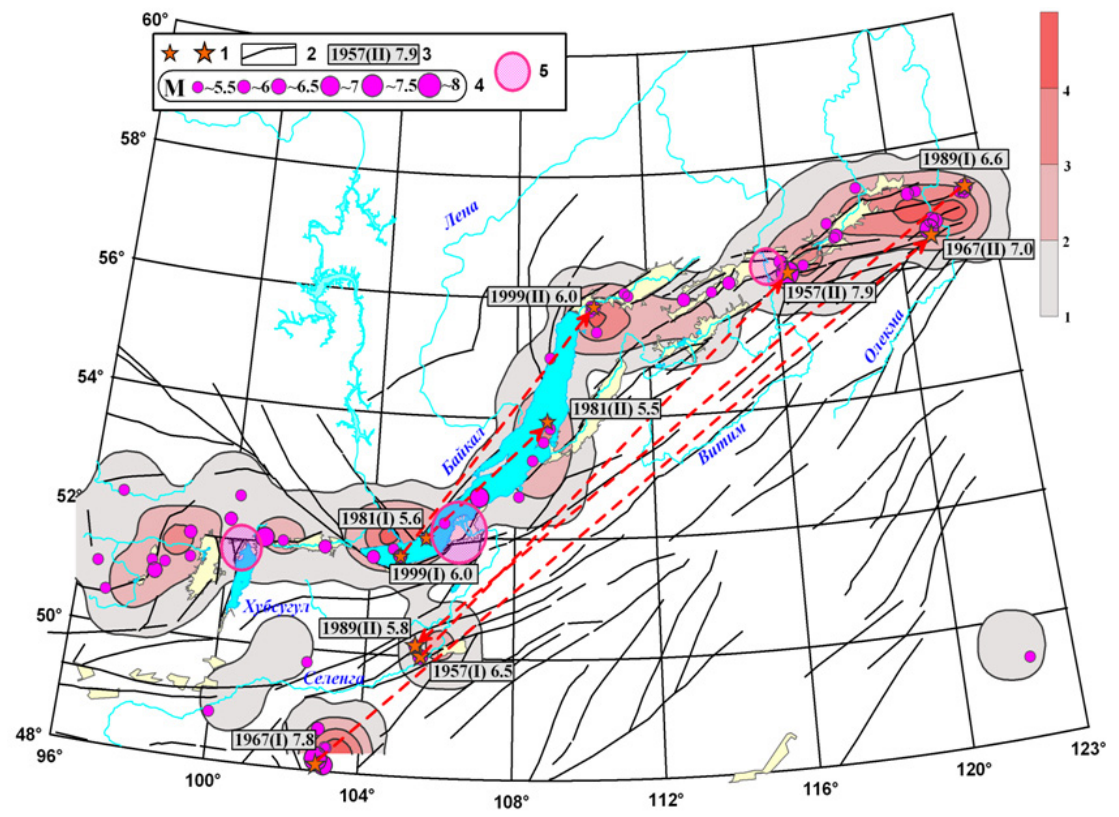

Рис. 7. Карта эпицентров и плотности эпицентров сильных землетрясений Байкальского региона с магнитудой $M_{L H} \geq 5.5$, произошедших с 1950 г.

1 - эпицентры пары сильных землетрясений; 2 - основные разломы; 3 - год; номер (первое (I) или второе (II) событие) и магнитуда толчка пары; 4 - эпицентры землетрясений с магнитудой $M_{L H} \geq 5.5,5$ - структуры-аттракторы рифтогенеза (CAP).

Fig. 7. The map of the Baikal region showing epicentres and density of strong earthquakes $\left(M_{L H} \geq 5.5\right)$ that took place from 1950 .

1 - epicentres of the couple of strong earthquakes; 2 - main faults; 3 - year and number $\left(1^{\text {st }}(\mathrm{I})\right.$ or $2^{\text {nd }}$ (II) event) and magnitude of the shock of the couple of earthquakes; 4 - epicentres of strong earthquakes $\left(M_{L H} \geq 5.5\right)$; 5 - structures acting as attractors of rifting (CAP). 
V.I. Dzhurik: Seismogeological, seismological and engineering seismological studies...

следует рассматривать как гипотезу, направленную на понимание тектонофизики литосферных процессов и описание региональной геодинамики и сейсмичности. Модель верифицируется в пространственно-временном и магнитудном распределении пар сильных землетрясений региона (рис. 7): все произошедшие за период инструментальных наблюдений пары пространственно разнесенных, но близких во времени сильных землетрясений с магнитудой $M_{L H}>5.5$ удовлетворяют основным выводам.

Современные знания о сейсмическом процессе и сильных землетрясениях позволяют считать, что они являются свойством одной из разновидностей широкого класса нелинейных диссипативных систем, имеющих противоположные тенденции стремления к порядку и к хаосу. В таких системах переходы от состояния равновесия к неустойчивому равновесию и локальной динамической неустойчивости, порождающие сильное землетрясение, возникают при условии притока энергии, а обратные переходы - при условии диссипации энергии. Одним из признаков состояния неустойчивого равновесия выступает явление генерации согласованных колебаний внутри системы или их проявление вследствие фазовой синхронизации с колебаниями во внешних системах. Такие признаки обнаружены при анализе стрессовых состояний [Ключевский, Ключевская, 2010] и исследовании эпизодов синхронизации толчков в Байкальском регионе и Монголии [Ключевский, Ключевская, 2009; Ключевский, 2010, 2011; Ключевский, Баяр, Бум-очир, 2010], а также при выделении парных сильных землетрясений.

На основе общефизической природы формирования цунами показано, что оно является атрибутом сейсмоопасных областей и регионов, граничащих с большими водоемами. Рассмотрены основные предпосылки и возможности явления цунами на оз. Байкал: информация о землетрясениях Байкальской впадины за инструментально-исторический период (1724-2011гг.) обобщена в карте эпицентров толчков с магнитудой $M \geq 5$ и гистограммах распределения чисел толчков по магнитуде [Ключевский и др., 2012]. Показано, что формирование волн цунами на Байкале начинается при землетрясениях с магнитудой $M \approx 5$, но из-за отсутствия системы мониторинга цунами на Байкале может наблюдаться только при сильнейших землетрясениях с $M>7$. В качестве примера приведено катастрофическое Цаганское землетрясение (1861 г., $M \approx 7.5$ ), произошедшее у восточного побережья оз. Байкал и вызвавшее цунами с человеческими жертвами.

Исследование сейсмотектонических смещений в литосфере БРС, выполненное по данным о динамических параметрах очагов землетрясений с энергетическим классом $K_{\mathrm{P}} \geq 7$ за 1968-1994 гг., позволило установить основные закономерности объемного течения горных пород в регионе [Ключевский, Демьянович, 2010]. Основной вклад в суммарные смещения вносят многочисленные слабые землетрясения, а максималь- ные перемещения геологического материала происходят в зонах продолжительных афтершоковых и роевых серий толчков. Полученные $3 D$ образы объемного сейсмотектонического течения в литосфере БРС указывают на хорошее соответствие отрицательных вертикальных перемещений горных пород рифтовым впадинам, а положительные движения совпадают с межвпадинными горными перемычками.

Напряженно-деформированное состояние литосферы БРС за 1968-1994 гг. исследовано по данным о динамических параметрах очагов более 80 тысяч землетрясений с энергетическим классом $6 \leq K_{\mathrm{P}} \leq 15$. За этот небольшой по геологическим масштабам интервал времени в литосфере БРЗ установлены три геодинамических эпизода перестройки напряжений. Природа перестроек связана с явлением инверсии осей главных напряжений, которое формируется процессами рифтогенеза и находит отражение в статистике сейсмических моментов толчков различных классов. Напряженно-деформированное состояние литосферы БРЗ обсуждается в рамках аналогий с установленными в физической мезомеханике закономерностями деформирования структурно-неоднородных сред [Ключевский, 2012].

\section{4. ПРОГНОЗ СЕЙСМИЧЕСКИХ ВОЗДЕЙСТВИЙ СИЛЬНЫХ} ЗЕМЛЕТРЯСЕНИЙ В РАЗЛИЧНЫХ КЛИМАТИЧЕСКИХ И СЕЙСМИЧЕСКИХ ЗОНАХ БАЙКАЛО-МОНГОЛЬСКОГО РЕГИОНА, РАЙОНИРОВАНИЕ СЕЙСМИЧЕСКОЙ ОПАСНОСТИ ТЕРРИТОРИЙ И ОЦЕНКА РЕАКЦИИ КРИТИЧЕСКИ ВАЖНЫХ ОБЪЕКТОВ НА СЕЙСМИЧЕСКИЕ СОБЫТИЯ

Прогноз параметров сейсмических волн сильных землетрясений Монголо-Байкальского региона, с учетом пространственно-временной изменчивости реологических свойств приповерхностного слоя земной коры, реализуется путем построения набора моделей, проведения теоретических расчетов, изучения в первом приближении динамики сейсмической опасности территорий, расположенных в зонах сплошной и островной мерзлоты (рис. 8). При изучении использовались макросейсмические сведения по сильным землетрясениям, данные комплекса инструментальных измерений и теоретические расчеты с использованием исходного сигнала, соответствующего местным сильным землетрясениям [Дреннов, Джурик и др., 2009].

В результате получен набор параметров, характеризующих изменение сейсмического риска при одинаковых сейсмических воздействиях, для относительно северных и южных районов Восточной Сибири и Южной Якутии (или для различных их климатических зон) (рис. 8). Показано, что переход к южным районам или деградация мерзлоты малой мощности приводит к усилению влияния приповерхностных неоднородностей, которые становятся значительными (сравнимыми с глубинными) на частотах сейсмических колебаний больше 3 Гц [Дреннов и др., 2013]. 
A

Твердомерзлые
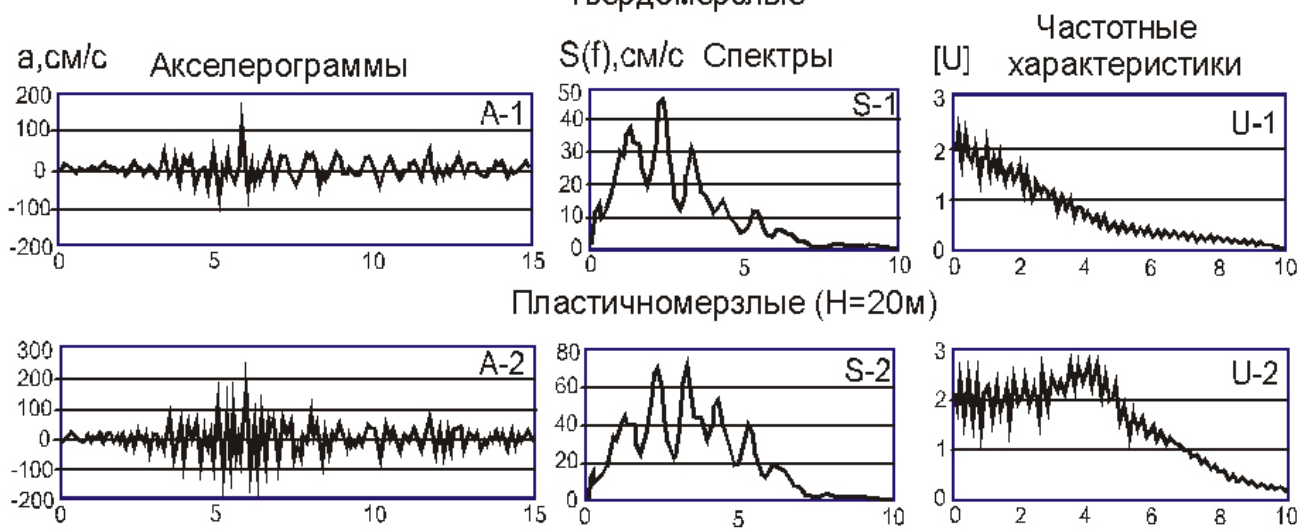

талые $(\mathrm{H}=300 \mathrm{~m})$
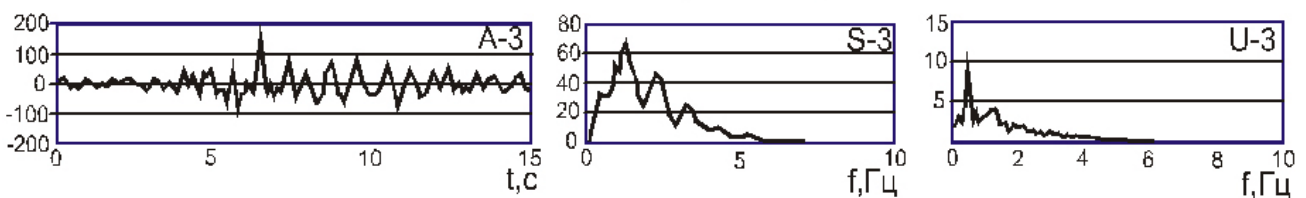

$\mathbf{5}$
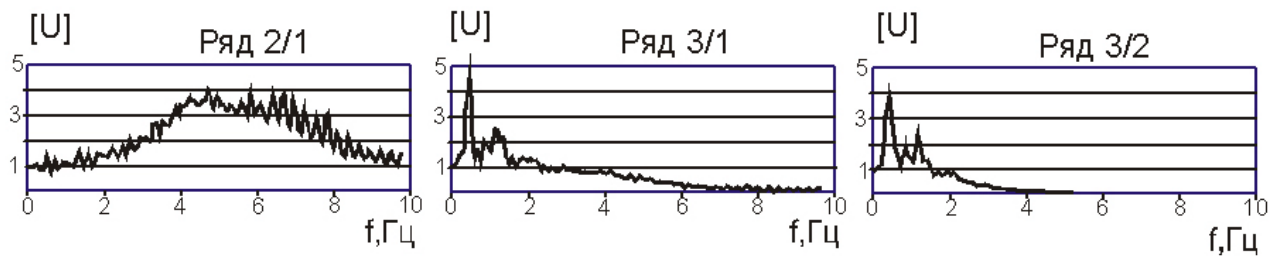

Рис. 8. Вероятные расчетные сейсмические характеристики при одинаковых сейсмических воздействиях на основания грунтовых моделей в переходных климатических зонах от мерзлого состояния грунтов к талым $(A)$ и относительные частотные характеристики верхних пачек слоев земной коры (Б).

Fig. 8. Estimated potential seismic characteristics under similar seismic effects on soil models for climate zones with transition from frozen soil to thawing soil $(A)$ and relative frequency characteristics of top layers of the crust $(Б)$.

При достаточном статистическом наборе регистрируемых инструментальными методами сейсмического микрорайонирования характеристик, обоснованном формировании исходного сигнала, с учетом основных параметров зон ВОЗ, отвечающих исходной сейсмичности территории строительства, и данных записей местных землетрясений, на уровне требований нормативных документов обеспечивается получение необходимого набора параметров сейсмических воздействий, учитывающих деградацию мерзлоты для проектирования сейсмостойких линейных сооружений (рис. 9) [Джурик и др., 2012].

Проведенные исследования направлены на обеспечение сейсмической безопасности при проектировании комплекса протяженных линейных сооружений в районах Сибири и охватывающих переходные зоны от сплошной мерзлоты к талым грунтам [Джурик, Серебренников, Дреннов и др., 2009; Джурик, Серебренников и др., 2011].

Предложена методика районирования сейсмической опасности исследуемых территорий по сейсмо- грунтовым моделям [Джурик и др., 2009]. Методика реализована на примере г. Эрдэнэт, Монголия (рис. 10). В итоге методически обосновано решение ряда задач проблемных этапов работ для исследуемых территорий, которые включают изучение основных закономерностей сейсмического режима и современного уровня исходной сейсмичности территории, выявление сейсмоактивных районов и оценку их вероятного сейсмического потенциала, построение сейсмических моделей для типовых грунтовых условий и проведение для них теоретических расчетов основных параметров сейсмических воздействий. Конечным результатом исследований осваиваемых территорий является их районирование по основным параметрам сейсмических воздействий, необходимым для проектирования сейсмостойких сооружений. Это, прежде всего, сейсмическая опасность в баллах, максимальные ускорения (для горизонтальной и вертикальной компонент), преобладающие периоды колебаний при сильном землетрясении и резонансные частоты рыхлой толщи. Такой подход нами реализован на 

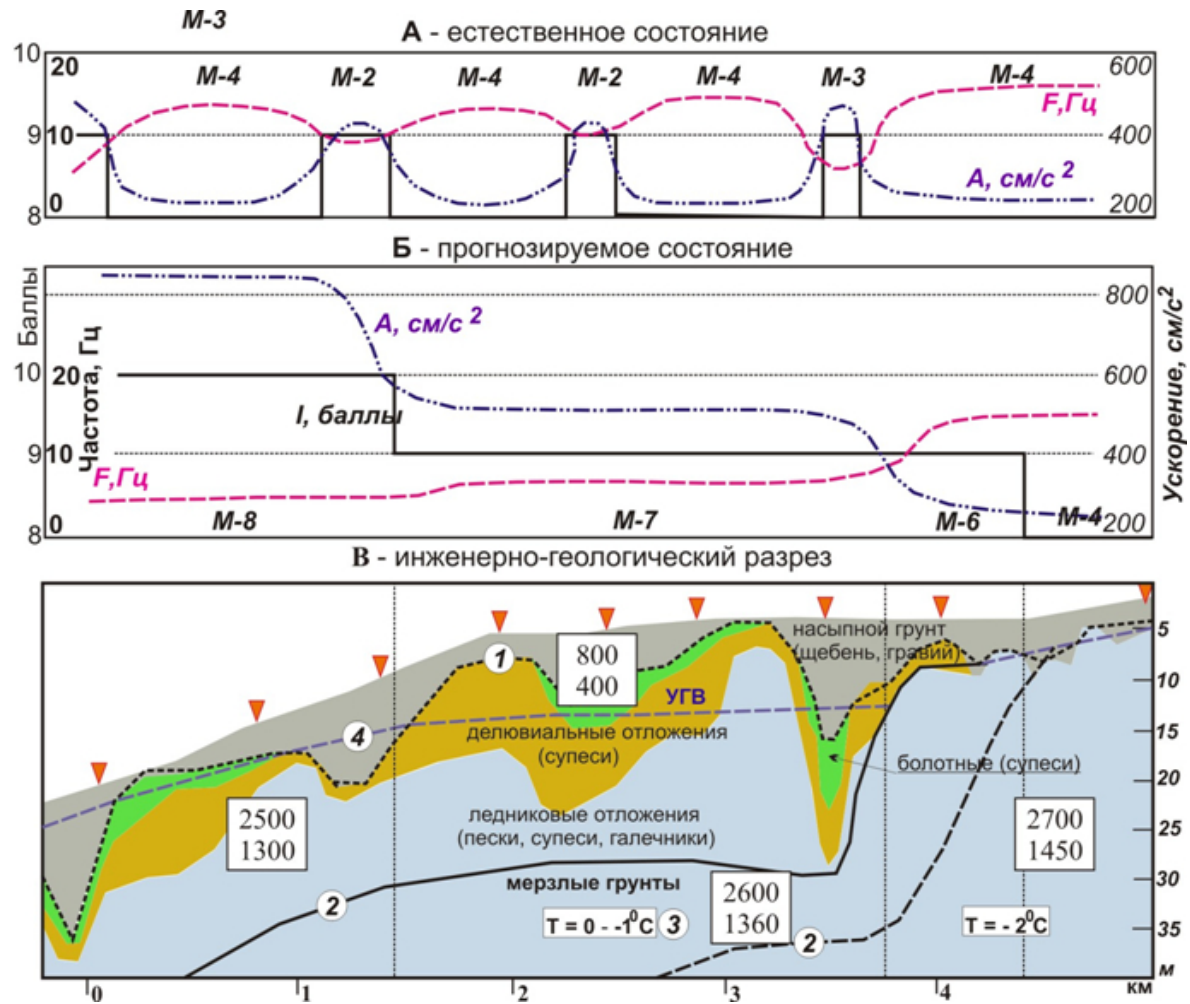

Рис. 9. Инженерно-сейсмогеологические условия строительства железной дороги в пределах расположения планируемой станции Икабьекан (Южная Якутия).

В квадратах представлены скорости сейсмических волн: сверху Vp, снизу Vs; треугольниками указаны пункты регистрации микросейсм и измерений скоростей сейсмических волн. 1 - граница мерзлоты - естественное состояние грунтов; 2 - граница мерзлоты - прогнозируемое состояние грунтов; 3 - температура мерзлых грунтов для их прогнозируемого состояния; 4 - УГВ - в прогнозируемом состоянии.

Fig. 9. Engineering seismogeological conditions of construction of the rail road in the area of Ikabjekan Station (in design), Southern Yakutia, Russia.

Seismic wave velocities are shown in boxes (top - Vp; bottom - Vs); triangles show microseism survey stations and seismic wave velocity measurement sites. 1 - permafrost boundary in case of the natural state of soils; 2 - permafrost boundary in case of the predicted state of soils; 3 - temperature of frosted soils for their predicted state; 4 - groundwater table in the predicted state.

примере сейсмического микрорайонирования территории г. Эрдэнэт в масштабе 1: 25000 (рис. 10) [Джурик, Батсайхан и др., 2009].

Основная направленность этих исследований заключалась в дальнейшем развитии методов и приемов прогноза сейсмических воздействий и разработке рекомендаций по проведению сейсмического микрорайонирования применительно к грунтовым условиям Монголо-Сибирского региона [Джурик, Серебренников, Рященко и др., 2011].

При использовании записей акселерограмм землетрясений, зарегистрированных в течение последних 10 лет сетью сейсмических станций Байкальского филиала ГС СО РАН, рассмотрены динамические параметры сейсмических сигналов и установлены диапазоны их изменений для относительно сильных землетрясений БРЗ. Получены эмпирические связи между основными динамическими характеристиками ускорений грунта от магнитуды и расстояния. Реализован пример про- гноза записей акселерограмм для различных эпицентральных расстояний и магнитуд, направленный на возможность их использования при формировании исходных сейсмических сигналов, с учетом наиболее опасных зон ВОЗ, на примере г. Иркутска (рис. 11) [Джурик и др., 2011].

В методическом плане представленные результаты указанных этапов исследований (рис. 10 и 11) могут служить основой районирования сейсмического риска перспективных для освоения территорий Монголии и Сибири [Джурик и др., 2012].

По записям поперечных кода-волн региональных землетрясений получены значения сейсмической добротности (Qc), частотного параметра (n) и коэффициента затухания $(\delta)$ сейсмических волн в литосфере юго-западного фланга Байкальской рифтовой системы. Наблюдается сильная зависимость добротности от частоты и длины окна: Qс меняется от $47 \pm 51$ до $1036 \pm 190$ для центральных частот 0.3 и 12.0 Гц при 

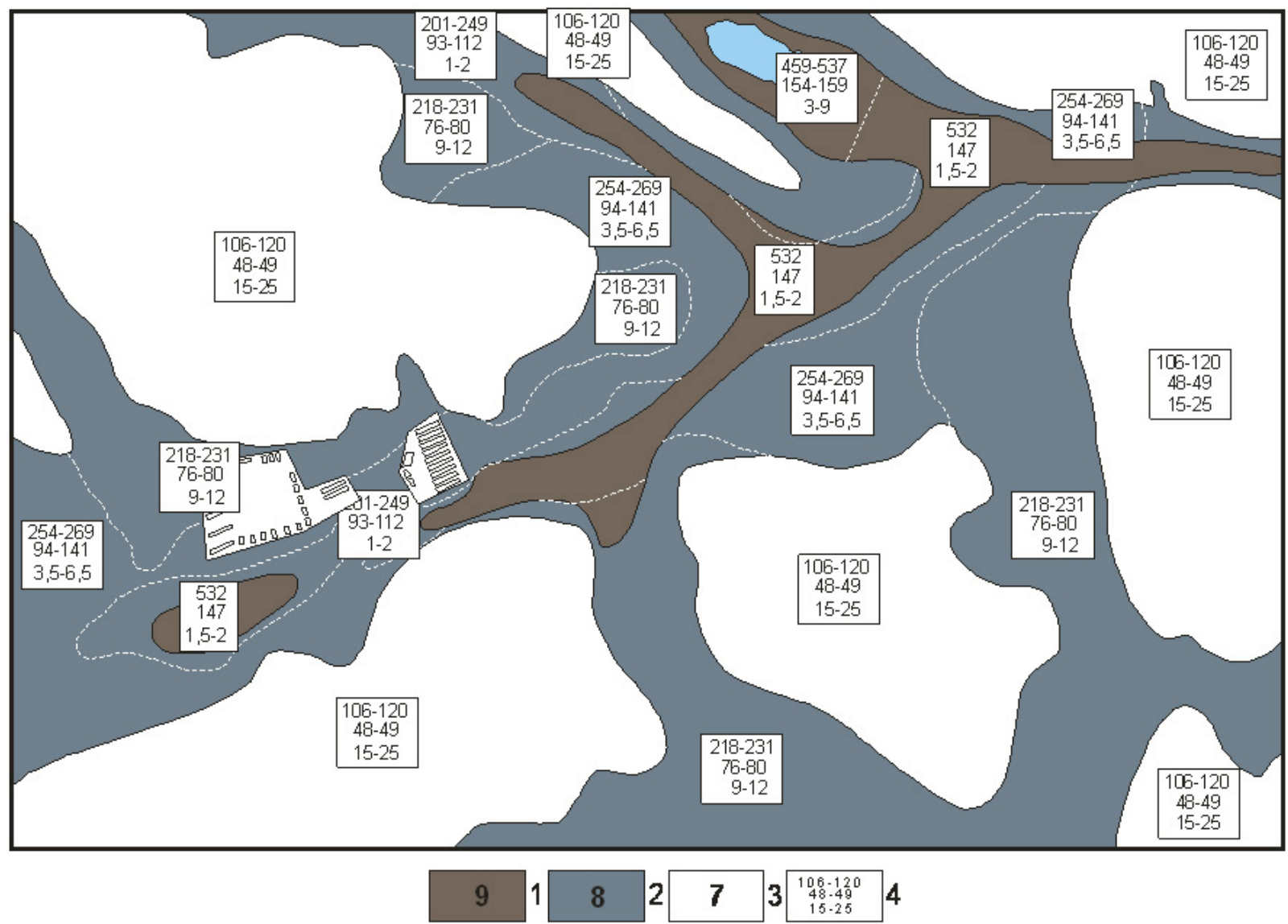

Рис. 10. Карта сейсмического микрорайонирования территории г. Эрдэнэт.

1-3 - зоны интенсивности сотрясений на средних грунтах в баллах (MSK-64); 4 - параметры сейсмических воздействий: верхнее значе-

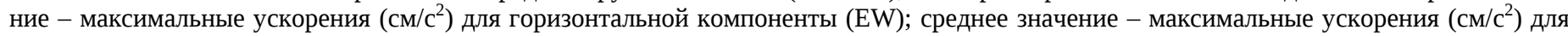
вертикальной компоненты (Z); нижнее значение - резонансные частоты рыхлого слоя (Гц).

Fig. 10. The seismic micro-zonation map of the city of Erdenet, Mongolia.

1-3 - zones of intensive shocks at medium soils as per MSK-64 intensity rates; 4 - parameters of seismic impacts: top value - maximum acceleration $\left(\mathrm{cm} / \mathrm{sec}^{2}\right)$ for horizontal component (EW); middle value - maximum acceleration $\left(\mathrm{cm} / \mathrm{sec}^{2}\right)$ for vertical component $(\mathrm{Z})$; bottom value - resonance frequencies of the loose layer $(\mathrm{Hz})$.

длине окна обработки коды $\mathrm{W}=20$ с и от $83 \pm 46$ до $1596 \pm 573$ на тех же частотах при $\mathrm{W}=60$ с. Значения добротности и коэффициента затухания рассчитаны для всей территории юго-западного фланга Байкальской рифтовой системы и для отдельных тектонических блоков: стабильной Сибирской платформы, горных поднятий Хамар-Дабана и Восточного Саяна, Южно-Байкальской и Тункинской впадин. Сопоставление результатов определений Qс с данными о возрасте, тектонике и уровне сейсмической активности рассматриваемых структур показало, что добротность зависит от современной тектонической активности структур и в меньшей степени от возраста коры [Добрынина, 2009, 2011; Dobrynina, 2011].

По результатам мониторинга сейсмических событий, ведущегося с 1997 г., инженерно-сейсмометрическими станциями (ИСС) на критически важных объектах (KBO) Прибайкалья получены новые данные о их реакции на сейсмические события: землетрясения, взрывы, микросейсмы, вибрации. По данным инженерно-сейсмометрических станций о работе системы «грунт-сооружение» усовершенствована методика инженерно-технического обследования зданий с использованием инструментальных методов. Проведение такого обследования позволило выявить ряд строений, которые внушают опасения, и принять обоснованные технические решения по восстановлению некоторых объектов, пострадавших от землетрясения.

Ретроспективный анализ данных ИСС подтверждает, что сильные движения, вызывающие явно нелинейное поведение грунтов и элементов конструкций с появлением значительных остаточных деформаций на поверхности земли, связаны с землетрясениями более 7 баллов. Остаточные деформации при 6-балльных сотрясениях не превышают 1-2 мм и могут иметь значение только для особо точных производств. При 

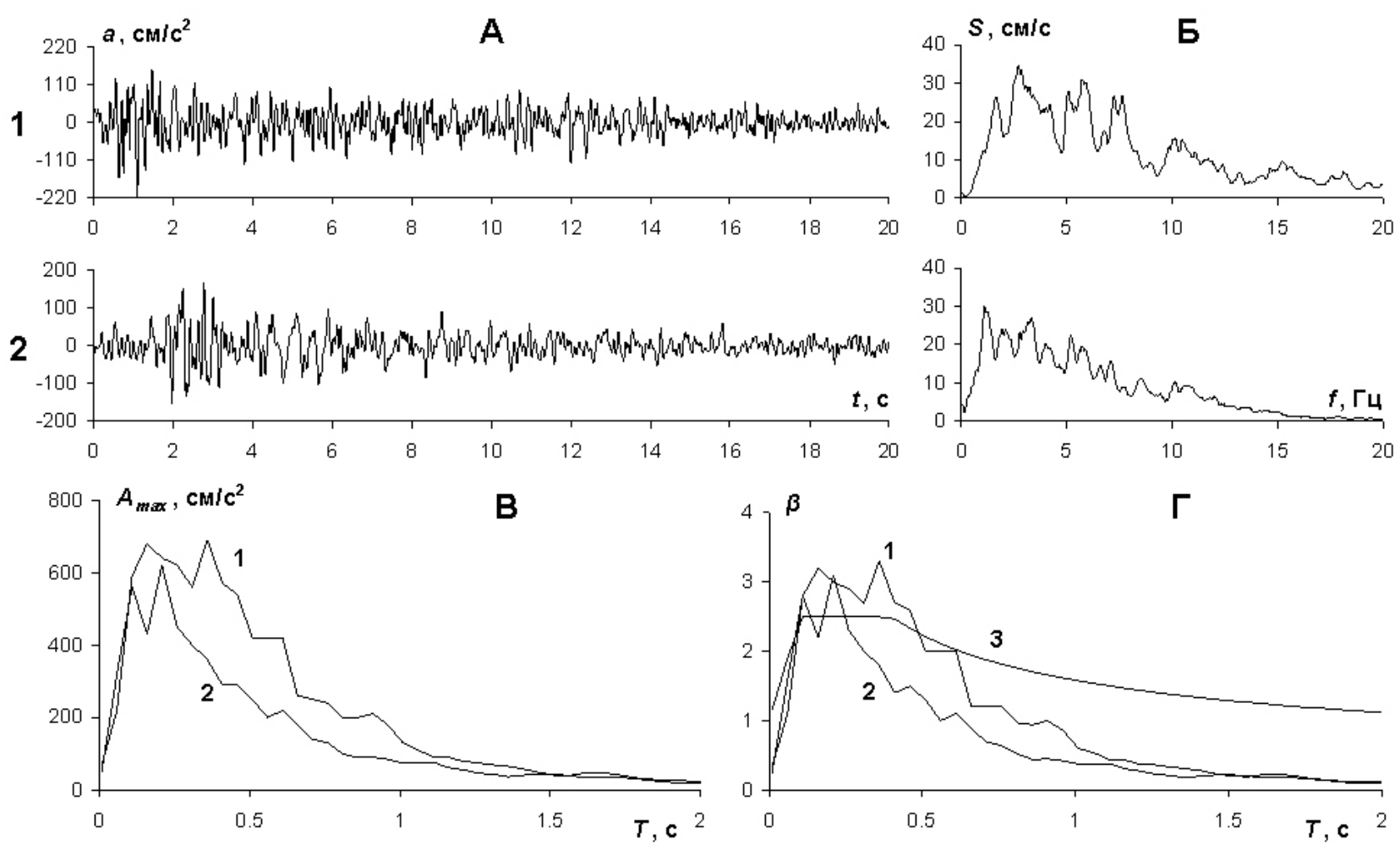

Рис. 11. Прогнозные акселерограммы (A), соответствующие им амплитудные спектры (Б), спектры реакции (B) и коэффициенты динамичности для рассматриваемых зон ВОЗ $(\Gamma)$.

1 - Восточно-Саянская зона ВОЗ; 2 - Южно-Байкальская зона ВОЗ; 3 - значения коэффициента динамичности ( $\beta \mathrm{i}$ ) в зависимости от расчетного периода собственных колебаний (Т), для территории г. Иркутска, согласно (СНиП II-7-81*).

Fig. 11. Forecasting accelerograms $(A)$, corresponding amplitude ranges $(\bar{b})$, response spectrums $(B)$, and dynamics coefficients for the reviewed zones of potential earthquake sources (PES) $(\Gamma)$.

1 - East Sayan zone of PES; 2 - South Baikal zone of PES; 3 - values of dynamics coefficients ( $\beta$ i) depending on duration of the period of estimations of intrinsic vibrations (T) for the territory of Irkutsk, according to Construction Standard SPNiP II-7-81*.

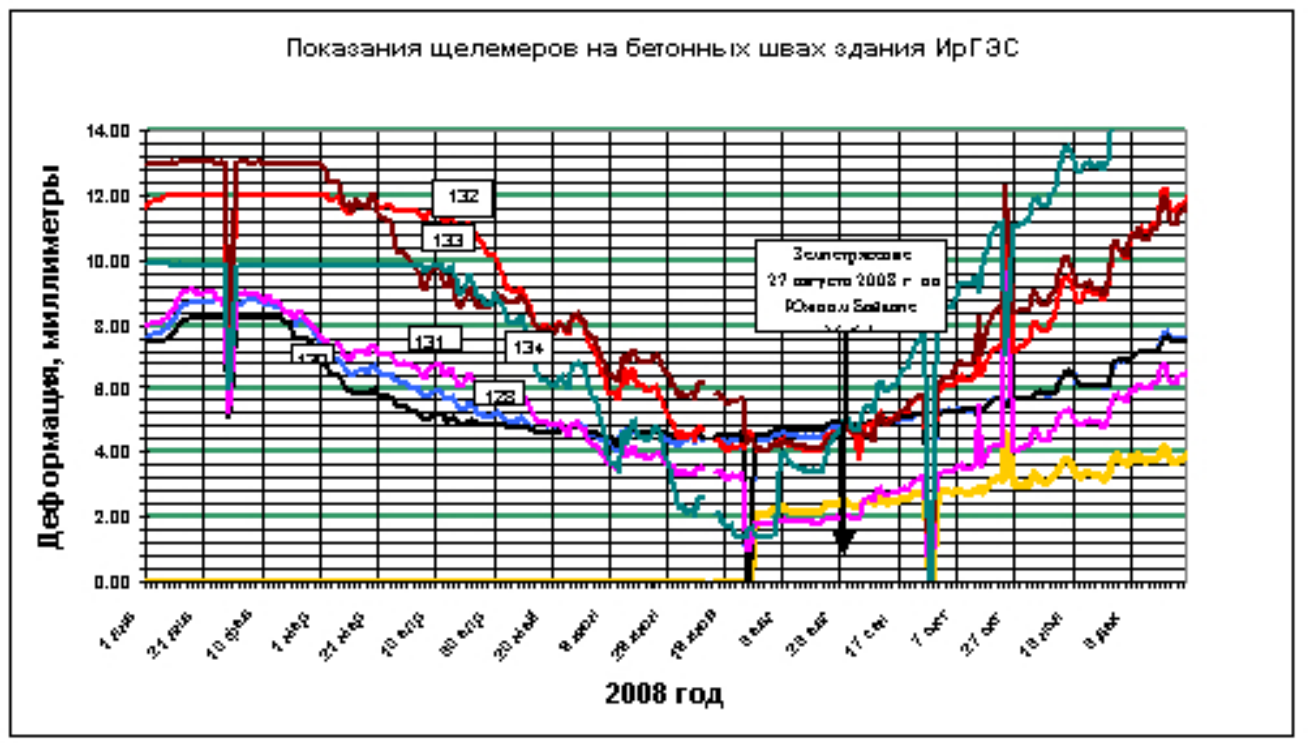

Рис. 12. Деформации бетонной плотины Иркутской ГЭС до и после Култукского землетрясения.

Fig. 12. The concrete dam of the Irkutsk Power Station before and after the Kultuk earthquake. 


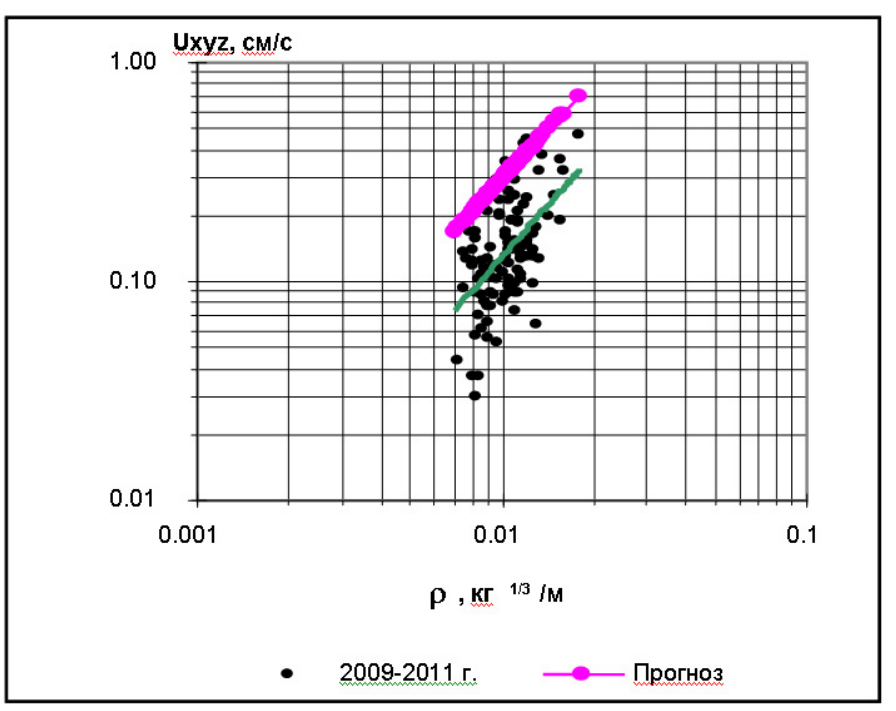

Рис. 13. Зависимость максимальной векторной скорости колебаний грунта от приведенного веса при взрывах 2009-2011 гг.

Fig. 13. Dependence of maximum vector velocities of ground vibrations from adjusted weights in case of explosions from 2009 to 2011.

накоплении таких деформаций от нескольких землетрясений они будут представлять опасность и для обычных сооружений (рис. 12) [Бержинский и др., 2013; Басов, Черных, 2010].

Рассмотрены вопросы определения количественных параметров землетрясений из зон возможных сильных землетрясений (BО3), механизмов и динамических параметров очагов для таких ответственных сооружений Прибайкалья, как Иркутская ГЭС, Ангарский электролизно-химический комбинат (АЭХК), Северомуйский тоннель. Выполнен анализ сейсмичности территорий, прилегающих к выделенным объектам, и сделаны предварительные оценки сейсмической опасности территории расположения объектов, дающие возможность понимания структуры сейсмической опасности, обусловленной пространственно-временной неоднородностью напряженно-деформированного состояния материала литосферы на локальных разломах [Семенов и др., 2011].

Выполнен прогноз количественных параметров динамических воздействий из зон ВОЗ и массовых взрывов для КВО. Определены параметры скорости колебаний грунта, и установлена максимальная векторная скорость при проведении массовых взрывов в глубоких карьерах (рис. 13). При экспериментах с небольшими взрывами были получены приближенные оценки остаточных деформаций сдвига в мягких сухих грунтах в условиях естественного залегания на глубине 1-2 м при сильных землетрясениях. Полученные оценки максимальных значений при 9-балльных со- трясениях составили около $10^{-3}$, а при 8-балльных порядка $5 \cdot 10^{-4}$. При этом остаточные деформации меньше упругих, которые и составляют основную часть полных деформаций [Черных и др., 2012].

В широком диапазоне периодов исследовались временные вариации амплитудных и спектральных характеристик микросейсмического фона на сейсмостанциях Прибайкалья. Для анализа периодичностей и цикличностей временных вариаций микроколебаний структурно-неоднородной среды привлекались также данные наблюдений временных сейсмостанций, регистрирующих колебания ледяного покрова оз. Байкал (рис. 14).

Предложен способ краткосрочного прогнозирования землетрясений, включающий инструментальный мониторинг в пределах локального участка литосферы сейсмоактивной зоны. В качестве прогнозного параметра используются низкочастотные микросейсмические колебания, проводится его спектрально-временной анализ, и по снижению уровня сигнала в спектральном окне 25-40 Гц определяется приближение сейсмического события и его параметры [Черных и дp., 2012].

Разработан способ выделения, обработки и интерпретации сейсмических волн на записях микросейсм, которые принимаются как интерференционно-модулированный сигнал, генерируемый источниками разной природы и прошедший амплитудно-частотные преобразования в результате распространения в сложноорганизованной структурно-неоднородной геологической среде. Он основывается на том, что сигналы, возникающие в естественных условиях, можно считать модулированными колебаниями. В технике связи модулирующие сигналы являются информационными, т.е. содержащими передаваемую информацию, тогда как несущее колебание, частота которого, как правило, много больше ширины спектра информационного сигнала, обеспечивает более эффективную передачу этой информации на расстояние. Обычно под модулированными колебаниями понимаются колебания, параметры которых (амплитуда, фаза, частота, длительность и т. п.) изменяются во времени. Однако это понятие распространяется и на колебания, параметры которых изменяются в пространстве, и тогда говорят о пространственно модулированных колебаниях: в отличие от временных модулированных колебаний они могут быть двух- и трехмерными. В общем случае модулированные колебания отражают пространственновременную модуляцию сигналов, в том числе и микросейсм [Черных, Ключевский, 2011; Черных, Ключевский, 2013].

\section{7. ОСНОВНЫЕ ВЫВОДЫ ПО РЕЗУЛЬТАТАМ РАБОТ}

Проведен спектральный анализ сильных землетрясений из основных зон ВОЗ для БРЗ по данным инст- 

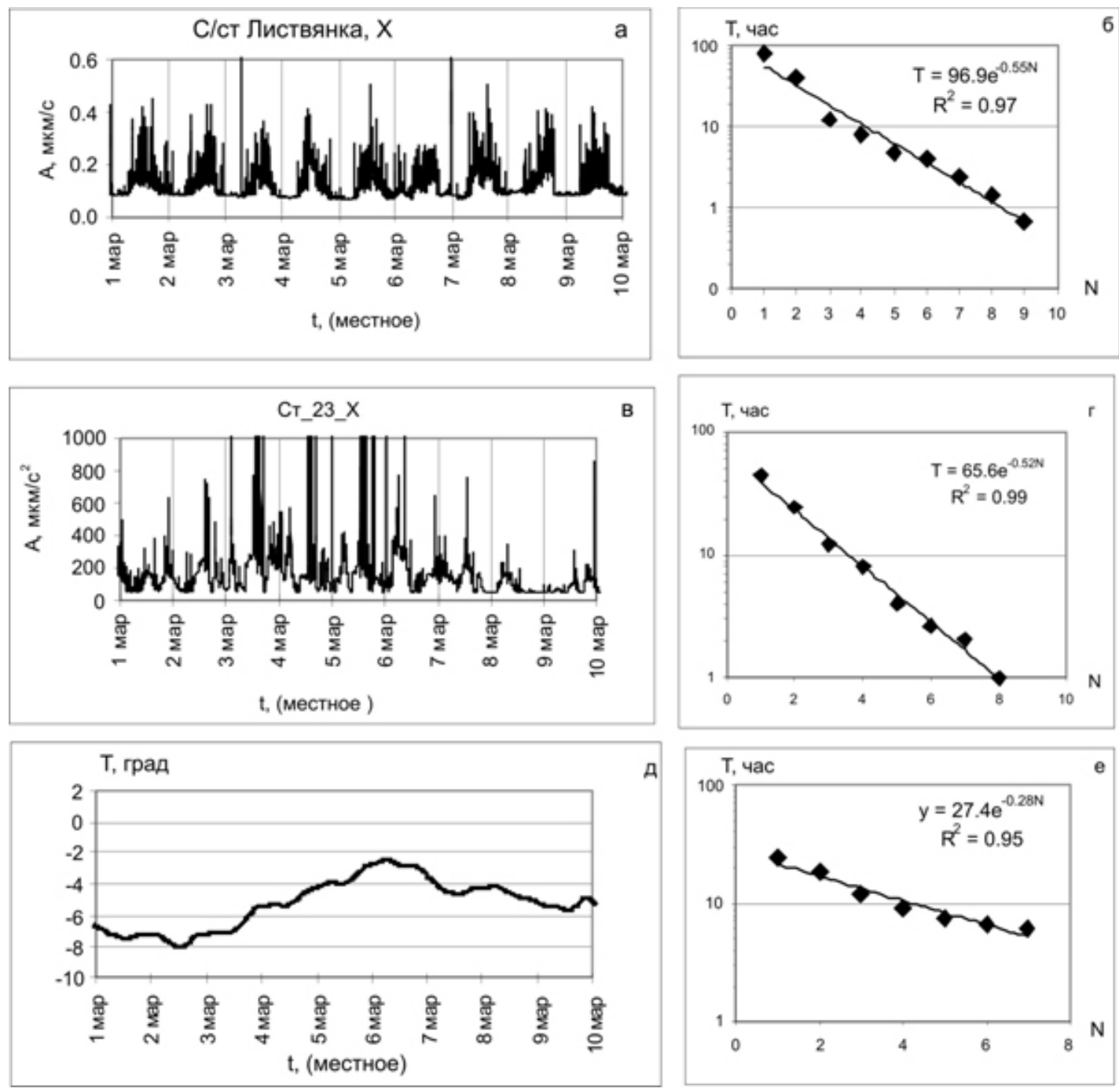

Рис. 14. Вариации уровней микросейсмических колебаний в 2013 г.: $a$ - сейсмостанция Листвянка; б - периоды выделенных периодичностей в микроколебаниях грунта; в - вариации уровня микроколебаний льда; д - периоды периодичностей в микроколебаниях льда, вариации температуры льда, $e$ - выделенные периоды в колебаниях температуры.

Fig. 14. Variable micro-seismic vibration levels in 2013: $a$ - Listvyanka seismic station; $\sigma$ - periods of identified regulations in micro-seismic vibration of soil; $в$ - variable micro-seismic vibration levels of ice; $\partial$ - periods of identified regulations in microseismic vibration of ice, variations of ice temperature; $e$ - identified periods in temperature changes.

рументальных наблюдений с привлечением расчетных методов, определены динамические параметры очагов землетрясений за 1995-2008 гг., составлен каталог динамических параметров очагов землетрясений за 19682008 гг., что позволит изучить напряженно-деформированное состояние среды и динамику происходящих в них процессов.

Разработаны принципы региональной классификации неотектонических структур с обоснованием их дифференциации по классам на основе анализа структурно-тектонических, геолого-геофизических и сейсмологических данных эталонных объектов в наиболее активизированных сегментах главных сейсмогенерирующих зон (Саяно-Байкальский и Верхоянский). Эти сведения вошли как основа в составление комплекта новых карт Общего сейсмического районирования Российской Федерации (ОСР-2012), которые характеризуют шесть уровней сейсмической опасности (А, В, C, D, E, F), предназначенных для применения при проектировании и сейсмостойком строительстве объектов разных типов и уровней ответственности. Основной вклад наших исследований в составление карт связан с представленными материалами по сейсмотектонике и динамике сейсмических процессов территории АлтаеСаяно-Байкальской и Якутской сейсмических зон РФ.

Обобщены результаты инженерно-сейсмологических исследований, выполненных за длительный период на обширных территориях Сибири и Монголии. Основная направленность этих работ заключалась в дальнейшем развитии методов и приемов прогноза 
сейсмических воздействий сильных землетряений и в разработке рекомендаций по проведению сейсмического микрорайонирования в пределах криолитозоны. Предложена методика изучения инженерно-сейсмологических условий строительства ряда крупных промышленных комплексов, протяженных трасс линейных сооружений и критически важных объектов (см. список литературы лаборатории с 2009 г.).

\section{8. ПЕРСПЕКТИВЫ РАЗВИТИЯ ЛАБОРАТОРИИ}

Перспективы развития лаборатории видятся в дальнейшем развитии комплексных геолого-геофизических исследований зон активных сейсмопродуцирующих разломов Восточной Сибири методами сейсмогеологического анализа и малоглубинной геофизики. Перспективным представляется проведение работ в зонах главных сейсмогенерирующих разломов Иркутской области и Прибайкалья методом лазерного сканирования при помощи беспилотных летательных аппаратов и лазерного сканера. Это даст возможность построения карт ДСР и СМР нового поколения.

Необходимо создание и экспериментальное обеспечение инженерно-сейсмологических полигонов по региональному сейсмическому мониторингу динамики параметров сильных сейсмических воздействий и сейсмической активности промышленных районов. В этом отношении важнейшими для Байкальской сейсмической зоны становятся задачи разработки новой методологии проведения средне- и мелкомасштабного сейсмического районирования и прогноза сейсмического воздействия на основе решения динамических задач очаговой и структурной сейсмологии с учетом физической нелинейности сейсмических волн и колебаний сооружений.

\section{9. ЛИТЕРАТУРА ПО ТЕМЕ ИССЛЕДОВАНИЙ 2009-2013 ГГ.}

\section{1. МоНОГРАФИИ:}

Джурик В.И., Батсайхан Ц., Серебренников С.П. Улаанбаатар хотын нутаг дэвсгэрийн газар ходлолтийн аюулын судалгаа. Улаанбаатар: MAS, 2009. 136 с.

Джурик В.И., Ключевский А.В., Серебренников С.П., Демьянович В.М., Батсайхан Ц., Баяраа Г. Сейсмичность и районирование сейсмической опасности территории Монголии. Иркутск: ИЗК СО РАН, 2009. 420 с.

Джурик В.И., Серебренников С.П., Рященко Т.Г., Батсайхан Ц., Дугармаа Т, Улзийбат М., Ескин А.Ю., Усынин Л.А. Районирование сейсмической опасности территории города Эрдэнэта. Иркутск: ИЗК СО РАН, 2011. 122 с.

Имаева Л.П., Мельникова В.И., Имаев В.С., Козьмин Б.М., Мельников А.И., Гриб Н.Н. Эволюция сейсмотектонических процессов восточного фланга Байкальской рифтовой зоны. Иркутск: ИЗК СО РАН, 2012. 232 с.

Лапердин В.К., Имаев В.С., Верхозин И.И., Качура Р.А., Имаева Л.П. Опасные геологические процессы на юге Якутии и сопредельных территориях. Иркутск: ИЗК СО РАН, 2011. 239 с.

Смекалин О.П., Имаев В.С., Чипизубов А.В. Палеосейсмология Восточной Сибири (некоторый опыт практического применения). Иркутск: ИЗК СО РАН, 2011. 101 с.

Трифонов В.Г., Додонов А.Е., Бачманов Д.М., Иванова Т.П., Караханян А.С., Имаев В.С., Никифоров С.П., Кожурин А.И., Аммар О., Рукие М., Аль-Кафри А.-М., Минини Х., Аль-Юсеф Ш., Али О., Гриб Н.Н., Соловьев В.Н., Имаева Л.П., Качаев А.В., Сясько А.А., Гусева Т.В., Али М., Заза Т., Юсеф А. Неотектоника, современная геодинамика и сейсмическая опасность Сирии. М.: Геос, 2012. 216 с.

\section{2. СТАТЬИ В ЗАРУБЕЖНЫХ РЕЦЕНЗИРУЕМЫХ ЖУРНАЛАХ}

Dobrynina A.A. Coda-wave attenuation in the Baikal rift system lithosphere // Physics of the Earth and Planetary Interiors. 2011. V. 188. P. 121-126. http://dx.doi.org/10.1016/j.pepi.2011.05.008.

Fujita K., Koz'min B.M., Mackey K.G., Riegel S.A., McLean M.S., Imaev V.S. Seismotectonics of the Chersky Seismic Belt, eastern Sakha Republic (Yakutia) and Magadan District, Russia // Stephan Mueller Spec. Publ. Ser. 2009. № 4. P. 117145.

Klyuchevskii A.V. An umbilic catastrophe as a model of rock failure in earthquakes // National Seismological Review of Russia, 2007-2010. P. 107-114. http://dx.doi.org/10.2205/2011-IUGG-NRR2007-2010.

Klyuchevskii A.V. Nonlinear geodynamics of the Baikal Rift System: an evolution scenario with triple equilibrium bifurcation // Journal of Geodynamics. 2010. V. 49. № 1. P. 19-23. http://dx.doi.org/10.1016/j.jog.2009.08.001.

Klyuchevskii A.V., Khlebopros R.G. Coupled large earthquakes in the Baikal rift system: Response to bifurcations in nonlinear resonance hysteresis // Geoscience Frontiers. 2013. V. 6. № 4. P. 709-716. http://dx.doi.org/10.1016/j.gsf.2013.01. 008.

Mackey K.G., Fujita K., Hartse H.E., Stead R.J., Steck L.K., Gunbina L.V., Leyshuk N., Shibaev S.V., Koz'min B.M., Imaev V.S., Gordeev E.I., Chebrov V.N., Masal'ski O.K., Gileva N.A., Bormatov V.A., Voitenok A.A., Levin Y.N., Fokina T.A 
V.I. Dzhurik: Seismogeological, seismological and engineering seismological studies...

Seismicity Map of Eastern Russia, 1960-2010 // Seismological Research Letters. 2010. V. 81. № 5. P. 761-768. http://dx.doi.org/10.1785/gssrl.81.5.761.

Semenov R.M. Earthquake of 27 August 2008 in the Southern Baikal area its precursors // Geodynamics \& Tectonophysics. 2010. V. 1. № 4. P. 441-447. http://dx.doi.org/10.5800/GT-2010-1-4-0028.

Smekalin O.P., Shchetnikov A.A., White D. Arshan palaeoseismic feature of the Tunka fault (Baikal rift zone, Russia) // Journal of Asian Earth Sciences. 2013. V. 62. P. 317-328. http://dx.doi.org/10.1016/j.jseaes.2012.10.011.

\section{3. СТАТЬИ В РОССИЙСКИХ РЕЦЕНЗИРУЕМЫХ ЖУРНАЛАХ}

Басов А.Д., Черных Е.Н. О наблюдении среднесрочного предвестника землетрясения в Иркутске // Физика Земли. 2010. № 1. С. 80-89.

Басов А.Д., Черных Е.Н., Шагун А.Н., Капралов А.П. Микродеформации на Иркутской ГЭС при землетрясении 27 августа 2008 г. на Южном Байкале // Сейсмостойкое строительство. Безопасность сооружений. 2009. № 4. C. 52-54.

Бержинский Ю.А., Бержинская Л.П., Горбач Л.С., Иванькина Л.И.,. Киселев Д.В., Саландаева О.И.,. Усатый Р.А., Черных Е.Н., Шагун А.Н. Реализация комплексной методики паспортизации жилищного фонда на примере г. Шелехова в рамках целевой программы по сеймобезопасности Иркутской области // Сейсмостойкое строительство. Безопасность сооружений. 2013. № 2. С. 54-61.

Бержинский Ю.А., Бержинская Л.П., Иванькина Л.И., Ордынская А.П., Саландаева О.И., Чигринская Л.С., Акулова B.B., Черных E.H. Оценка сейсмической надежности жилых и общественных зданий при землетрясении 27.08.2008 г. на Южном Байкале // Вопросы инженерной сейсмологии. 2009. Т. 36. № 1. С. 23-39.

Бержинский Ю.А., Ордынская А.П., Гладков А.С., Лунина О.В., Бержинская Л.П., Радзиминович Н.А., Радзиминович Я.Б., Имаев В.С., Смекалин О.П., Чипизубов А.В. Опыт применения шкалы ESI2007 для оценки интенсивности Култукского землетрясения 27.08.2008 г., Южный Байкал // Вопросы инженерной сейсмологии. 2009. Т. 36. № 3. C. 5-26.

Бернгардт О.И., Добрынина А.А., Жеребцов Г.А., Михалев А.В., Перевалова Н.П., Ратовский К.Г., Рахматулин Р.А., Саньков В.А., Сорокин А.Г. Геофизические явления, сопровождавшие падение Челябинского метеороида // Доклады АН. 2013. Т. 452. № 2. С. 205-207.

Бесстрашнов В.М., Имаев В.С., Стром А.Л. Еще раз о палеосейсмодислокациях в северо-западной части зоны Главного Саянского разлома в свете уроков некоторых катастрофических землетрясений // Геориск. 2010. № 4. С. 54 58.

Демберел С., Батарсурэн Г., Имаев В.С., Стром А.Л., Смекалин О.П., Чипизубов А.В., Гриб Н.Н., Сясько А.А., Качаев A.В. Палеосейсмогенные деформации в окрестностях Улан-Батора по геологическим и геофизическим данным // Вопросы инженерной сейсмологии. 2010. Т. 37. № 3. С. 45-54.

Джурик В.И., Дреннов А.Ф., Серебренников С.П. Расчет акселерограмм сильных землетрясений для г. Иркутска из различных зон ВОЗ // Сейсмостойкое строительство. Безопасность сооружений. 2012. № 5. С. 64-69.

Джурик В.И., Серебренников С.П., Батсайхан Ц., Дреннов А.Ф., Брыжак Е.В., Усынин Л.А., Ескин А.Ю. Методика районирования сейсмической опасности приграничных территорий Монголо-Сибирского региона (на примере района г. Эрдэнэт) // Известия Иркутского государственного университета. Серия «Науки о Земле». 2012. Т. 5. № 1. С. 118-142.

Джурик В.И., Серебренников С.П., Брыжак Е.В., Дреннов А.Ф., Ескин А.Ю. Методика формирования исходного сейсмического сигнала с целью районирования сейсмической опасности городских агломераций (на примере г. Иркутска) // Известия Иркутского государственного университета. Серия «Науки о Земле». 2012. Т. 5. № 2. С. 96-110.

Джурик В.И., Серебренников С.П., Дреннов А.Ф., Брыжак Е.В., Усынин Л.А., Шагун А.Н., Ескин А.Ю. К районированию сейсмической опасности территории г. Иркутска // Известия Иркутского государственного университета. Серия «Науки о Земле». 2011. Т. 4. № 2. С. 61-81.

Джурик В.И., Серебренников С.П., Дреннов А.Ф., Усынин Л.А. Районирование сейсмической опасности протяженных трасс линейных сооружений в Сибирском регионе // Вопросы инженерной сейсмологии. 2009. Т. 36. № 4. C. 53-59.

Джурик В.И., Серебренников С.П., Ескин А.Ю., Усынин Л.А., Брыжак Е.В., Шагун А.Н. Инженерно-сейсмологическое обеспечение безопасности строительства линейных сооружений в сейсмоактивных районах Южной Якутии с учетом деградации мерзлоты // Известия Иркутского государственного университета. Серия «Науки о Земле». 2011. Т. 4. № 1. С. 60-78.

Джурик В.И., Серебренников С.П., Ключевский А.В., Батсайхан Ц. Комплексная оценка сейсмической опасности участков строительства зданий в г. Улаанбаатаре // Сейсмостойкое строительство. Безопасность сооружений. 2009. № 5. C. 46-51.

Джурик В.И., Серебренников С.П., Рященко Т.Г., Ескин А.Ю., Усынин Л.А., Брыжак Е.В., Батсайхан Ц., Дугармаа Т. Районирование сейсмической опасности территории г. Эрдэнэт на основе количественных характеристик колебаний грунтов при сильных землетрясениях // Сейсмостойкое строительство. Безопасность сооружений. 2010. № 2. С. 38-43. 
Джурик В.И., Серебренников С.П., Усынин Л.А., Брыжак Е.В., Ескин А.Ю., Шагун А.Н. Пример комплексной оценки сейсмической опасности участка строительства аэропорта «Горячинск» // Известия Иркутского государственного университета. Серия «Науки о Земле». 2013. Т. 6. № 1. С. 28-45.

Джурик В.И., Серебренников С.П., Шагун А.Н., Ескин А.Ю., Усынин Л.А., Брыжак Е.В. Опыт районирования линейных сооружений в пределах криолитозоны по максимальным ускорениям при использовании экспериментальных частотных характеристик // Сейсмостойкое строительство. Безопасность сооружений. 2012. № 2. С. 59-64.

Добрецов Н.Л., Ружич В.В., Псахье С.Г., Черных Е.Н., Шилько Е.В., Левина Е.А., Пономарева Е.И. О совершенствовании способов прогноза землетрясений средствами физического моделирования в ледовом покрове Байкала // Физическая мезомеханика. 2011. Т. 14. № 4. С. 69-79.

Добрынина А.А. Очаговые параметры землетрясений Байкальской рифтовой системы // Физика Земли. 2009. № 12. C. 60-75.

Добрынина А.А., Саньков В.А. Скорости и направления распространения разрывов в очагах землетрясений Байкальской рифтовой системы // Геофизические исследования. 2010. Т. 11. № 2. С. 52-61.

Добрынина А.А., Чечельницкий В.В., Саньков В.А. Сейсмическая добротность литосферы юго-западного фланга Байкальской рифтовой системы // Геология и геофизика. 2011. № 5. С. 712-724.

Дреннов А.Ф., Джурик В.И., Дреннова Н.И. Оценка сейсмических воздействий Байкальской рифтовой зоны // Вопросы инженерной сейсмологии. 2009. Т. 36. № 4. С. 42-52.

Дреннов А.Ф., Джурик В.И., Серебренников С.П., Брыжак Е.В., Дреннова Н.Н. Спектры ускорений колебаний, возбуждаемых землетрясениями юго-западного фланга Байкальской рифтовой зоны // Геология и геофизика. 2013. Т. 54. № 2. C. 292-301.

Дреннов А.Ф., Джурик В.И., Серебренников С.П., Дреннова Н.Н. Влияние верхней зоны разреза на амплитудночастотный состав сейсмического сигнала на примере сейсмических станций Прибайкалья и Забайкалья // Сейсмические приборы. 2010. Т. 46. № 2. С. 48-58.

Дэмбэрэл С., Имаев В.С., Рогожин Е.А., Смекалин О.П., Улзийбат М., Чипизубов А.В. К уточнению сейсмической опасности г. Улан-Батор (Монголия) // Вопросы инженерной сейсмологии. 2013. Т. 40. № 1. С. 19-32.

Имаев В.С., Смекалин О.П., Стром А.Л., Чипизубов А.В., Сясько А.А. Оценка сейсмической опасности г. Улан-Батор (Монгольская Народная Республика) по результатам сейсмогеологических исследований // Геология и геофизика. 2012. T. 53. № 9. С. 1182-1193.

Имаев В.С., Имаева Л.П., Козьмин Б.М. Сейсмотектонический анализ Яно-Индигирского сегмента зоны Черского // Физика Земли. 2010. № 12. С. 79-86.

Имаев В.С., Имаева Л.П., Козьмин Б.М., Стром А.Л. Сейсмотектонические деформации центральной части Алданского щита // Отечественная геология. 2010. № 5. С. 84-89.

Имаев В.С., Стром А.Л., Чипизубов А.В, Смекалин О.П., Имаева Л.П., Лободенко И.Ю. Перспективы использования лазерного сканирования при проведении палеосейсмологических исследований в Сибири // Геотектоника. 2013. № 3. С. 78-86.

Имаева Л.П., Имаев В.С., Козьмин Б.М. Сейсмогеодинамика Алдано-Станового блока // Тихоокеанская геология. 2012. T. 31. № 1. C. 5-18.

Имаева Л.П., Имаев В.С., Козьмин Б.М. Сейсмотектонический анализ Яно-Индигирского сегмента зоны Черского // Физика Земли. 2011. № 12. С. 1-14.

Имаева Л.П., Козьмин Б.М., Имаев В.С. Активизация сейсмотектонических процессов на западе Олекмо-Становой сейсмической зоны // Отечественная геология. 2013. № 6. С. 37-43.

Имаева Л.П., Козьмин Б.М., Имаев В.С. Динамика очаговых зон сильных землетрясений северо-восточного фланга Момо-Селенняхских впадин // Отечественная геология. 2011. № 5. С. 113-119.

Имаева Л.П., Козьмин Б.М., Имаев В.С. Динамика сейсмогенных структур Индигиро-Колымского (Охотского) сегмента зоны хр. Черского // Отечественная геология. 2012. № 5. С. 55-61.

Имаева Л.П., Мельникова В.И., Имаев В.С. Сейсмотектоническая деструкции земной коры северо-восточного фланга Байкальской рифтовой зоны // Доклады АН. 2012. Т. 443. № 4. С. 492-494.

Ключевский А.В. О представлении очага землетрясения элементарной катастрофой "омбилики" // Сейсмостойкое строительство. Безопасность сооружений. 2009. № 3. С. 43-45.

Ключевский А.В. Влияние изменений энергетического класса землетрясений Байкальского региона на параметры графика повторяемости // Вулканология и сейсмология. 2010. № 4. С. 58-68.

Ключевский А.В. Корреляции скорости потока землетрясений Байкальского региона и Монголии: эпизоды синхронизации // Физика Земли. 2010. № 4. С. 35-45.

Ключевский А.В. Аттракторы рифтогенеза как атрибут кайнозойского этапа эволюции литосферы Байкальской рифтовой системы // Доклады АН. 2011. Т. 440. № 6. С. 811-814.

Ключевский А.В. Структуры-аттракторы рифтогенеза в литосфере Байкальской рифтовой системы // Доклады АН. 2011. T. 437. № 2. С. 249-253. 
V.I. Dzhurik: Seismogeological, seismological and engineering seismological studies...

Ключевский А.В. Эпизоды высокой корреляции годовых чисел землетрясений Байкальской рифтовой зоны // Вулканология и сейсмология. 2011. № 1. С. 55-62.

Ключевский А.В. Напряженно-деформированное состояние литосферы Байкальской рифтовой зоны: некоторые аналогии с установленными в физической мезомеханике закономерностями деформирования структурно-неоднородных сред // Физическая мезомеханика. 2012. Т. 15. № 3. С. 23-34.

Ключевский А.В. Сейсмоэнергетические бреши в литосфере Байкальского региона // Природные и техногенные риски. Безопасность сооружений. 2013. № 2. С. 29-31.

Ключевский А.В. Статистика основных параметров очагов сильных землетрясений Байкальского региона // Сейсмостойкое строительство. Безопасность сооружений. 2013. № 3. С. 46-50.

Ключевский А.В., Баяр Г., Бум-очир С. Эпизоды синхронизации годовых чисел землетрясений Монголо-Байкальского региона // Доклады АН. 2010. Т. 431. № 1. С. 107-112.

Ключевский А.В., Демьянович В.М. Байкальская рифтовая зона: область повышенной энергии сейсмотектонических деформаций литосферы // Доклады АН. 2009. Т. 428. № 5. С. 663-666.

Ключевский А.В., Демьянович В.М. Основные закономерности объемного сейсмотектонического течения горных пород в литосфере Байкальской рифтовой зоны // Доклады АН. 2010. Т. 433. № 1. С. 97-101.

Ключевский А.В., Демьянович В.М., Демберел С., Лхагвадорж Б. Карта энергии сейсмотектонических деформаций литосферы Монголии // Сейсмостойкое строительство. Безопасность сооружений. 2011. № 1. С. 47-51.

Ключевский А.В., Демьянович В.М., Джурик В.И. Иерархия сильных землетрясений Байкальской рифтовой системы // Геология и геофизика. 2009. Т. 50. № 3. С. 279-288.

Ключевский А.В., Демьянович В.М., Джурик В.И. Оценки энергии сейсмотектонических деформаций литосферы Байкальской рифтовой зоны // Вулканология и сейсмология. 2013. № 4. С. 40-56.

Ключевский А.В., Демьянович В.М., Джурик В.И., Черных Е.Н., Серебренников С.П. Карта энергии сейсмотектонических деформаций литосферы Байкальского региона // Сейсмостойкое строительство. Безопасность сооружений. 2009. № 4. С. 49-51.

Ключевский А.В., Демьянович В.М., Дэмбэрэл С., Лхагвадорж Б. Энергия сейсмотектонических деформаций литосферы Монголии // Доклады АН. 2012. Т. 442. № 4. С. 495-499.

Ключевский А.В., Демьянович В.М., Ключевская А.А. О возможности цунами на озере Байкал // Доклады АН. 2012. T. 442. № 2. C. 254-258.

Ключевский А.В., Зуев Ф.Л. Фрактальные оценки сейсмического процесса в литосфере Байкальского региона // Литосфера. 2011. № 1. С. 143-149.

Ключевский А.В., Ключевская А.А. Сейсмический процесс в литосфере Байкальской рифтовой зоны: эпизоды синхронизации // Доклады АН. 2009. Т. 425. № 2. С. 240-244.

Ключевский А.В., Ключевская А.А. Эффекты синхронизации и десинхронизации при стрессе в геологической и биологической системах // Геофизические процессы и биосфера. 2009. Т. 8. № 3. С. 26-45.

Ключевский А.В., Ключевская А.А. Эпизоды синхронизации сейсмического процесса в Байкальском регионе и Монголии // Сейсмостойкое строительство. Безопасность сооружений. 2010. № 3. С. 65-67.

Ключевский А.В., Ружич В.В. Сравнительное исследование записей близких землетрясений на скальном грунте и ледовом покрове озера Байкал // Сейсмические приборы. 2012. Т. 48. № 4. С. 39-50.

Лапердин В.К., Имаев В.С. Геологические опасные процессы в зоне Байкальского рифта и сопредельных территорий // Вопросы инженерной сейсмологии. 2010. Т. 37. № 1. С. 40-55.

Леви К.Г., Бержинская Л.П., Бержинский Ю.А., Гилева Н.А., Имаев В.С., Лухнев А.В., Масальский О.К., Мельникова В.И., Ордынская А.П., Радзиминович Н.А., Радзиминович Я.Б., Ружич В.В., Саньков В.А., Смекалин О.П., Черных Е.Н., Чечельницкий В.В. Култукское землетрясение // Природа. 2009. № 7. С. 56-63.

Лопатин М.Н., Семенов Р.М. Подземные воды Южного Прибайкалья - источник информации для прогноза землетрясений // Современные технологии. Системный анализ. Моделирование. 2013. № 3 (39). С. 187-193.

Мельникова В.И., Гилева Н.А., Имаев В.С., Радзиминович Я.Б., Тубанов Ц.А. Особенности сейсмических активизаций Среднего Байкала в 2008-2011 годах // Доклады АН. 2013. Т. 453. № 6. С. 1-6.

Мельникова В.И., Радзиминович Я.Б., Гилева Н.А., Радзиминович Н.А., Папкова А.А. Балейское землетрясение 6 января 2006 г.: отражение современной тектонической активности Восточного Забайкалья // Доклады АН. 2011 T. 437. № 6. C. 828-832.

Никитин Р.Я., Васильев А.В., Хон В.И., Черных Е.Н. Сейсмометрические исследования воздействия массовых взрывов в карьере на охраняемые объекты рудника «Интернациональный» // Горный журнал. 2012. № 2. С. 14-16.

Очковская М.Г., Радзиминович Н.А. Предварительные результаты анализа афтершоковых последовательностей Байкальской рифтовой зоны // Известия Иркутского государственного университета. Серия «Науки о Земле». 2011. T. 4. № 1. С.164-172.

Псахье С.Г., Шилько Е.В., Астафуров С.В., Димаки А.В., Гранин Н.Г., Ружич В.В., Гнатовский Р.Ю. Роль внутренних напряжений в плитных средах как фактора, определяющего деформационную активность на границах разде- 
ла. Оценка величины избыточных «тектонических» напряжений // Физическая мезомеханика. 2010. Т. 13. № 3. C. 98-103.

Радзиминович Н.А. Глубины очагов землетрясений Байкальского региона: обзор // Физика Земли. 2010 . № 3. C. 37-51.

Радзиминович Я.Б., Имаев В.С., Радзиминович Н.А., Ружич В.В., Смекалин О.П., Чипизубов А.В. Эффекты Култукского землетрясения 27 августа 2008 года с $\mathrm{M}_{\mathrm{W}}=6.3$ в ближней к эпицентру зоне: результаты макросейсмического обследования // Вопросы инженерной сейсмологии. 2009. Т. 36. № 1. С. 56-71.

Радзиминович Я.Б., Мельникова В.И., Середкина А.И., Гилева Н.А., Радзиминович Н.А., Папкова А.А. Землетрясение 6 января 2006 г. $(\mathrm{Mw}=4.5):$ редкий случай проявления сейсмической активности в Восточном Забайкалье // Геология и геофизика. 2012. Т. 53. № 10. С. 1-20.

Ружич В.В., Псахье С.Г., Черных Е.Н., Борняков С.А., Гранин Н.Г. Деформации и сейсмические явления в ледяном покрове озера Байкал // Геология и геофизика. 2009. Т. 50. № 3. С. 289-299.

Семенов Р.М., Имаев В.С., Смекалин О.П., Чипизубов А.В., Оргильянов А.И. Гелий в глубинной воде Байкала - предвестник землетрясений // Доклады АН. 2010. Т. 432. № 4. С. 533-536.

Семенов Р.М., Ключевский А.В., Черных Е.Н. Количественная оценка динамических параметров землетрясений для построения геомеханической модели Северомуйского тоннеля // Современные технологии. Системный анализ. Моделирование. 2011. № 2. С. 156-169.

Семенов Р.М., Лопатин М.Н. Поиск краткосрочных предвестников землетрясений в Южном Прибайкалье // Известия Иркутского государственного университета. Серия «Науки о Земле». 2013. Т. 6. № 1. С. 183-189.

Семенов Р.М., Малевич Л.В., Оргильянов А.И., Смекалин О.П. Исследования по поиску краткосрочных предвестников землетрясений в Прибайкалье // Сейсмостойкое строительство. Безопасность сооружений. 2011. № 4. C. 43-46.

Семенов Р.М., Смекалин О.П. Сильное землетрясение на Байкале 27 августа 2008 г. и его предвестники // Геология и геофизика. 2011. Т. 52. № 4. С. 521-528.

Смекалин О.П., Имаев В.С., Чипизубов А.В. Палеосейсмологические исследования в зоне Хустайского разлома // Геология и геофизика. 2013. Т. 54. № 7. С. 940-951.

Смекалин О.П., Чипизубов А.В., Имаев В.С. Палеоземлетрясения Прибайкалья: методы и результаты датирования // Геотектоника. 2010. № 2. С. 77-96.

Черных Е.Н., Басов А.Д., Семенов Р.М. Деформационные процессы на Северомуйском тоннеле // Современные технологии. Системный анализ. Моделирование. 2012. № 2 (34). С. 71-79.

Черных Е.Н., Ключевский А.В. Выделение в записях микросейсм интерфейсных волн, генерируемых рифтом озера Байкал // Природные и техногенные риски. Безопасность сооружений. 2013. № 5. С. 34-38.

Черных Е.Н., Ключевский А.В., Ружич В.В. Сравнительное исследование записей катастрофического ВосточноЯпонского землетрясения на скальном грунте и ледовом покрове озера Байкал // Вопросы инженерной сейсмологии. 2011. Т. 38. № 4. С. 29-38.

Чипизубов А.В., Имаев В.С., Смекалин О.П. О кинематике активного Баргузинского разлома // Вопросы инженерной сейсмологии. 2012. Т. 38. № 4. С. 49-58.

Шибаев С.В., Петров А.Ф., Козьмин Б.М., Имаева Л.П., Тимиршин К.В. Сейсмический риск на территории г. Якутска // Наука и образование. 2010. № 2. С. 4-10.

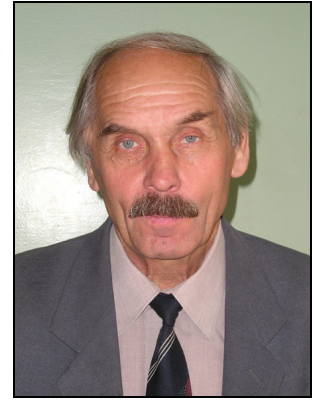

Джурик Василий Ионович, докт. геол.-мин. наук, заведующий лабораторией инженерной сейсмологии и сейсмогеологии

Институт земной коры СО РАН

664033, Иркутск, ул. Лермонтова, 128, Россия

Тел. (3952)427510; $₫$ e-mail: dzhurik@crust.irk.ru

Dzhurik, Vasiliy I., Doctor of Geology and Mineralogy, Head of Laboratory of Engineering Seismology and Seismogeology

Institute of the Earth's Crust, Siberian Branch of RAS

128 Lermontov street, Irkutsk 664033, Russia

Tel. +7(3952)427510; \ e-mail: dzhurik@crust.irk.ru 